\title{
Assessment of island beach erosion due to sea level rise: the case of the Aegean archipelago (Eastern Mediterranean)
}

\author{
Isavela N. Monioudi ${ }^{1}$, Adonis F. Velegrakis ${ }^{1}$, Antonis E. Chatzipavlis ${ }^{1}$, Anastasios Rigos ${ }^{1,2}$, Theophanis Karambas ${ }^{3}$, \\ Michalis I. Vousdoukas ${ }^{4,1}$, Thomas Hasiotis ${ }^{1}$, Nikoletta Koukourouvli ${ }^{5}$, Pascal Peduzzi ${ }^{6}$, Eva Manoutsoglou ${ }^{1}$, \\ Serafim E. Poulos ${ }^{7}$, and Michael B. Collins ${ }^{8}$ \\ ${ }^{1}$ Department of Marine Sciences, University of the Aegean, University Hill, 81100 Mytilene, Greece \\ ${ }^{2}$ Department of Cultural Technology and Communication, University of the Aegean, University Hill, \\ Mytilene 81100, Greece \\ ${ }^{3}$ School of Civil Engineering, Aristotle University of Thessaloniki, University Campus, \\ 54124 Thessaloniki, Greece \\ ${ }^{4}$ European Commission, Joint Research Centre (JRC), Directorate for Space, Security and Migration \\ Disaster Risk Management Unit, Via E. Fermi 2749, 21027 Ispra (VA), Italy \\ ${ }^{5}$ Department of Geography, University of the Aegean, University Hill, 81100 Mytilene, Greece \\ ${ }^{6}$ UNEP/DEWA/GRID-Geneva, International Environment House, 11 Chemin des Anémones, \\ 1219 Châtelaine, Switzerland \\ ${ }^{7}$ Faculty of Geology and Geoenvironment, National and Kapodistrian University of Athens, \\ Panepistimioupoli Zografou, 15784 Athens, Greece \\ ${ }^{8}$ Plentziako Itsas Estazioa, University of the Basque Country, Areatza z/g, 48620 Plentzia-Bizkaia, Spain
}

Correspondence to: Michalis I. Vousdoukas (michalis.vousdoukas@jrc.ec.europa.eu)

Received: 17 October 2016 - Discussion started: 7 November 2016

Revised: 17 January 2017 - Accepted: 4 February 2017 - Published: 21 March 2017

\begin{abstract}
The present contribution constitutes the first comprehensive attempt to (a) record the spatial characteristics of the beaches of the Aegean archipelago (Greece), a critical resource for both the local and national economy, and (b) provide a rapid assessment of the impacts of the longterm and episodic sea level rise (SLR) under different scenarios. Spatial information and other attributes (e.g., presence of coastal protection works and backshore development) of the beaches of the 58 largest islands of the archipelago were obtained on the basis of remote-sensed images available on the web. Ranges of SLR-induced beach retreats under different morphological, sedimentological and hydrodynamic forcing, and SLR scenarios were estimated using suitable ensembles of cross-shore (1-D) morphodynamic models. These ranges, combined with empirically derived estimations of wave runup induced flooding, were then compared with the recorded maximum beach widths to provide ranges of retreat/erosion and flooding at the archipelago scale. The spatial information shows that the Aegean "pocket" beaches may be particularly
\end{abstract}

vulnerable to mean sea level rise (MSLR) and episodic SLRs due to (i) their narrow widths (about $59 \%$ of the beaches have maximum widths $<20 \mathrm{~m}$ ), (ii) their limited terrestrial sediment supply, (iii) the substantial coastal development and (iv) the limited existing coastal protection. Modeling results indeed project severe impacts under mean and episodic SLRs, which by 2100 could be devastating. For example, under MSLR of $0.5 \mathrm{~m}$ - representative concentration pathway (RCP) 4.5 of the Fifth Assessment Report (AR5) of the Intergovernmental Panel on Climate change (IPCC) - a storm-induced sea level rise of $0.6 \mathrm{~m}$ is projected to result in a complete erosion of between 31 and $88 \%$ of all beaches (29-87\% of beaches are currently fronting coastal infrastructure and assets), at least temporarily. Our results suggest a very considerable risk which will require significant effort, financial resources and policies/regulation in order to protect/maintain the critical economic resource of the Aegean archipelago. 


\section{Introduction}

Beaches are critical components of the coastal zone; not only are they significant habitats in their own right (e.g., Defeo and McLachlan, 2013), but they also provide protection from marine flooding to other transitional ecosystems and the coastal assets, infrastructure and activities they front (e.g., Neumann et al., 2015). At the same time, tourism has been increasingly associated with beach recreational activities according to the dominant "Sun, Sea and Sand - 3S tourism" model (Phillips and Jones, 2006). Consequently, beaches have become very important economic resources (Ghermandi and Nunes, 2013) forming one of the pillars of tourism, an economic sector that contributes an estimated $5 \%$ of Gross Domestic Product (GDP), and about 6-7\% of global employment (directly and indirectly) (Hall et al., 2013).

Beaches are also very dynamic environments, controlled by complex forcing-response processes that operate at various spatiotemporal scales (Short and Jackson, 2013). They are generally under erosion (Eurosion, 2004; IPCC SREX, 2012; IPCC, 2013), which can be differentiated into (a) longterm erosion, i.e., irreversible retreat of the shoreline, due to mean sea level rise (MSLR) and/or negative coastal sedimentary budgets that force either beach landward migration or drowning (Nicholls and Cazenave, 2010), and (b) short-term erosion caused by storm surges and waves which, may or may not, result in permanent shoreline retreats but can be nevertheless devastating (e.g., Smith and Katz, 2012; UNECE, 2013). The accelerating MSLR coupled with episodic storm events will aggravate the already significant beach erosion with severe impacts on coastal activities, infrastructure and assets (e.g., Jiménez et al., 2012), and the beach carrying capacity for recreation/tourism (Valdemoro and Jiménez, 2006; McArthur, 2015).

Beach erosion appears to be particularly alarming in islands. Island beaches are increasingly vulnerable to erosion due to their (generally) limited dimensions and diminishing sediment supply (e.g., Velegrakis et al., 2008; Peduzzi et al., 2013). At the same time, island beaches are amongst the most significant $3 \mathrm{~S}$ tourism destinations. For example, $3 \mathrm{~S}$ tourism accounts for more than $23 \%$ of the Gross Domestic Product in many Caribbean Small Island Developing States and in some cases, e.g., Antigua and Barbuda, for more than $75 \%$ (ECLAC, 2011). Mediterranean islands are also major tourism destinations; in Greece, most of the hotel capacity and foreign tourist arrivals and earnings are associated with the Greek islands (SETE, 2016).

Under a variable and changing climate, projections on the future evolution of beach morphology are not easy due to uncertainties regarding both forcing and beach response (e.g., Short and Jackson, 2013). Nevertheless, beach erosion is amongst the first issues to consider when planning for the sustainable development of the coastal zone, particularly in areas where beaches function as natural "armor" to valuable coastal infrastructure and assets and/or as significant environments of leisure (e.g., Paula et al., 2013). Therefore, assessments of the beach morphological evolution at different spatiotemporal scales are required based on advanced numerical, analytical and/or empirical models constructed and applied by experienced operators and set up/validated using appropriate field data and backed by expert analysis (e.g., Roelvink et al., 2009; Bosom and Jiménez, 2010; Ding et al., 2013). However, such efforts are usually hampered by the (a) scarcity of relevant information in many coastal areas and (b) dearth in the necessary human and financial resources (e.g., Parker et al., 2013); this is particularly true when assessments of beach erosion are carried out over larger spatial scales. Nevertheless, it is necessary to assess future beach retreat/erosion and flood risk at large spatial scales in order to identify "hot spots" and plan for effective adaptation policies and efficient allocation of resources.

Against this background, the objective of the present study is to assess the erosion and temporary inundation/flood risks of the beaches of the Aegean archipelago islands (Greece) under different scenarios of sea level rise (SLR). Towards this objective, spatial characteristics such as the area, length, maximum width, orientation, sediments and the presence of coastal works and backshore development of the Aegean beaches were recorded. This information was then used in conjunction with projections from ensembles of cross-shore morphodynamic models to obtain estimates of the ranges of potential beach retreat/erosion and flooding under different MSLRs and storm conditions.

\section{Aegean archipelago beaches: significance, environmental setting and sea level rise}

\subsection{Significance of the Aegean archipelago beaches}

The Aegean archipelago (Fig. 1) consists of several thousand islands and rock islets with a combined area of $17550 \mathrm{~km}^{2}$ and a total coastline length of about $5880 \mathrm{~km}$ (Eurosion, 2004). Few of these islands and islets are populated; less than 70 islands have more than 100 permanent inhabitants and 45 have more than 1000 (http://www.statistics.gr/en/ interactive-map). Yet Aegean islands form very significant tourist destinations. About $50 \%$ of all Greek hotel beds (and $>60 \%$ of all 5 star hotel beds) are located in the Aegean archipelago, with $43 \%$ of the foreign arrivals to Greece in 2015 (7.4 out of a total of 17.1 million) arriving at its 11 international airports (SETE, 2016).

In recent years, tourism has become a most significant economic activity in Greece. In 2013, foreign earnings of the Greek tourist industry were about EUR 15.5 billion (http://www.bankofgreece.gr/Pages/el/ Statistics/externalsector/balance/travelling.aspx). As recent studies suggest that for each EUR 1 generated by tourism in Greece an additional EUR 1.2-1.65 is created by related 
economic activity (a multiplier of, at least, 2.2; see IOBE, 2012), it follows that direct and indirect earnings from tourism may account for up to about $20 \%$ of the country's GDP (and $30 \%$ of the private sector employment). Tourism is even more important for the island (local) economies. For example, in 2012 tourism accounted for about $48 \%$ of the GDP of Crete and $60 \%$ of the GDP of the Cyclades and Dodecanese island complexes (SETE, 2016).

In the Aegean archipelago, $3 \mathrm{~S}$ tourism is the dominant model. A most critical component of $3 \mathrm{~S}$ tourism is the availability of beaches that are environmentally and aesthetically sound and retain adequate carrying capacity (e.g., McArthur, 2015; Cisneros et al., 2016). Therefore, the assessment/management of beach erosion which could constitute a major risk for the sustainable development of the Aegean islands beaches should be prioritized; a decade-old approximation had suggested that about $25 \%$ of the total coastline of the Aegean islands was already under erosion (Eurosion, 2004).

\subsection{Environmental setting}

The Aegean archipelago is located in the Aegean Sea, a peripheral sea of the Eastern Mediterranean that covers an area of some $160 \times 103 \mathrm{~km}^{2}$, drains high relief basins with a total area of $200 \times 103 \mathrm{~km}^{2}$ and is connected to Black Sea through the Dardanelles straits and to Eastern Mediterranean through the Cretan Arc straits. The Aegean Sea has a high relief due to complex regional tectonics and comprises different geomorphological units (Poulos, 2009), including an extensive shelf (N. Aegean shelf), a tectonic trough (N. Aegean Trough), a central platform (Cyclades plateau) with a large concentration of islands and deep basins (Fig. 1). The Aegean Sea shows complex hydrographic patterns and circulation (e.g., Theocharis et al., 1993) which are mainly controlled by the cold and low salinity water inputs from the Black Sea through the Dardanelles strait and the warm and saline water inputs from the Levantine Sea through the eastern Cretan Arc straits (Skliris et al., 2011). Under certain conditions (the Eastern Mediterranean transient), the Aegean basins can be important locations of deep water formation in the Eastern Mediterranean (e.g., Zervakis et al., 2000; Androulidakis et al., 2012).

The complex physiography of the Aegean archipelago controls its wind and wave climate, which is generally relatively mild due to the short fetches and durations. Northerly winds ( $44 \%$ frequency of occurrence, Androulidakis et al., 2015) and waves (Soukissian et al., 2007, 2008) appear to prevail. Although waves are generally more energetic in winter, there are also energetic events in summer, forced by $\mathrm{N}-$ NE winds ("the etesians"). Highly energetic wave events of relatively short duration may also occur, particularly along island straits. Soukissian et al. (2008) suggested (i) the area to the N-NE of the Cyclades platform (particularly the Mykonos-Ikaria strait) and (ii) the western and eastern Cre- tan Arc straits (Fig. 1) as the most energetic areas of the Aegean archipelago; for example, maximum wave heights of about $11 \mathrm{~m}\left(T_{p}\right.$ of $13.3 \mathrm{~s}$ and direction of $\left.345^{\circ} \mathrm{N}\right)$ have been reported for the Mykonos-Ikaria strait (22 January 2004). An Analysis of ERA-Interim wave information (1979-2013) from different representative areas of the Aegean archipelago carried out as part of the present study shows (a) mean significant wave heights $\left(H_{\mathrm{s}}\right)$ of about $1 \mathrm{~m}$ in all areas, apart from an area to the northeast of eastern Cretan Arc straits (mean $H_{\mathrm{s}}$ of about $0.8 \mathrm{~m}$ ); (b) mean maximum wave heights of about $2.4 \mathrm{~m}$; and (c) significant interannual variability.

Recent studies on the future wave climate of the Aegean archipelago project small changes in significant wave heights for the 21st century. For the period 2001-2049, significant wave heights in the N. Aegean are projected to slightly increase for the SW waves relative to the 1950-2000 reference period; whereas for the end of the century (2050-2099), wave occurrence and heights are projected to show high spatiotemporal variability (e.g., Prinos, 2014; Tsoukala et al., 2016).

\subsection{Mean and extreme sea levels}

Mediterranean MSLR rates were $1.1-1.3 \mathrm{~mm} \mathrm{yr}^{-1}$ for most of the 20th century. Since the late 1990s, however, much higher rates $\left(2.4-3.8 \mathrm{~mm} \mathrm{yr}^{-1}\right)$ have been recorded, an increase attributed mainly to additional water mass inputs rather than to steric contributions; these changes have been also related to North Atlantic Oscillation (NAO) modulations (Tsimplis et al., 2013). For the Aegean archipelago in particular, satellite altimetry suggests recent MSLR rates of 4.3-4.6 $\mathrm{mm} \mathrm{yr}^{-1}$ (Mamoutos et al., 2014), with some periods characterized by even higher rates (e.g., Tsimplis et al., 2009). In terms of future projections, recent studies project decreases in the MSLR rates in the 21st century, although this might be an underestimation due to the uncertainties regarding the mass exchanges particularly between the Black and Aegean Seas (Mamoutos et al., 2014). Hinkel et al. (2014), using an approach accounting for changes in ice mass and ocean circulation, projected the following MSLRs for the region of the Aegean archipelago $\left(33.5-40^{\circ} \mathrm{N}, 18.5-28.5^{\circ} \mathrm{E}\right)$. In 2050, MSL was projected to be $0.13-0.15$ and $0.14-16 \mathrm{~m}$ higher than that of the 1985-2005 reference period for a medium land ice scenario and RCPs of 4.5 and 8.5, respectively; in 2100 , under the same scenarios, MSL was projected to be $0.46-0.48$ and $0.66-0.72 \mathrm{~m}$ higher than that of the 1985-2005 reference period, respectively.

In addition to MSLR, changes in the intensity, frequency and/or patterns of extreme storm surges and waves can, at least temporarily, induce beach erosion and flooding, particularly when combined with increasing mean sea levels (MSLs)(e.g., Xu and Huang, 2013). Extreme sea levels (ESLs) in the Mediterranean have a seasonal footprint with extreme positives occurring mostly in winter and under cer- 


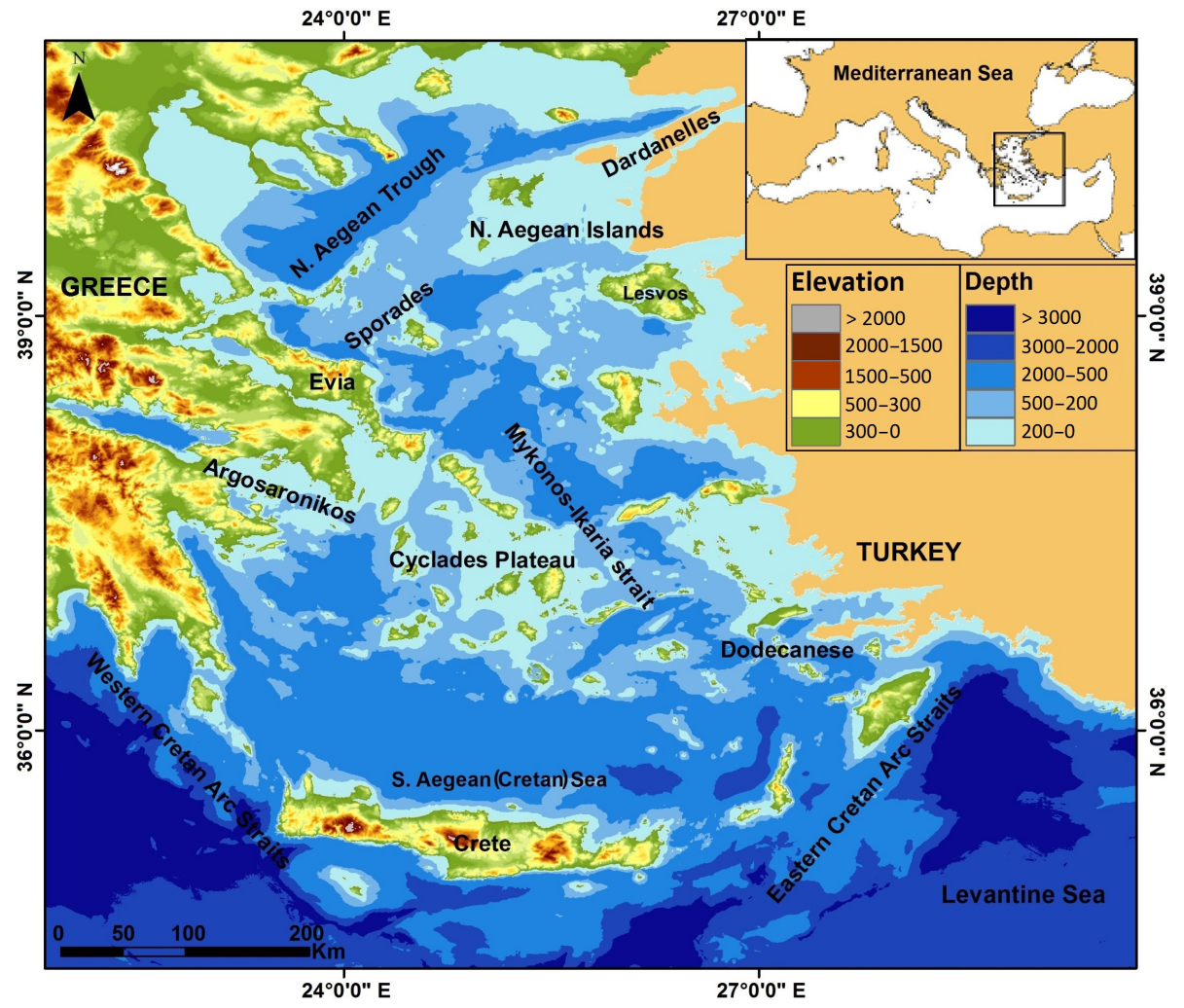

Figure 1. The Aegean archipelago.

tain North Atlantic Oscillation modulations (Tsimplis and Shaw, 2010).

Future ESLs are projected to show high spatial variability, being sensitive to the evolution of the thermohaline circulation and the Black Sea buoyant inputs (e.g., Mamoutos et al., 2014). Generally, extreme levels due to storm surges and waves are projected to decrease in terms of magnitude over the Mediterranean basin towards the end of the 21st century (e.g., Conte and Lionello, 2013), although model choice and resolution and the quality/resolution of the coastal observations available for model validation may have influenced these projections (e.g., Calafat et al., 2014). For example, a recent study has suggested substantial changes in the return periods of ESLs for the E. Mediterranean for the end of the 21 st century, with the current 1000 -year event projected to occur every five years (Vousdoukas et al., 2017). Regarding the storm surges in the Aegean archipelago, these are relatively small (heights of up to about $0.5 \mathrm{~m}$, Krestenitis et al., 2011) and projected to show (generally) small height increases until 2050 as well as changes in their temporal distribution (e.g., Marcos et al., 2011; Androulidakis et al., 2015; Vousdoukas et al., 2016a).

\section{Materials and Methods}

\subsection{Geospatial characteristics of the Aegean archipelago beaches}

The geospatial characteristics of Aegean archipelago ("dry") beaches have been recorded on the basis of the imagery and other related optical information available in the Google Earth Pro application. In this study, dry beaches were defined as the low-lying coastal sedimentary bodies bounded on their landward side by either natural boundaries (vegetated dunes and/or cliffs) or permanent artificial structures (e.g., coastal embankments, sea walls, roads, and buildings) and on their seaward side by the shoreline, i.e., the median line of the foaming swash zone shown on the imagery. Regarding the lateral extent of individual beaches, these were delimited by natural barriers such as rock promontories. Tiny beaches (areas less than about $20 \mathrm{~m}^{2}$ ) were ignored and not included in the data set. Digitization of the remote-sensed imagery was carried out by few (four) analysts who consistently followed the above beach delimitation rules. To assess inconsistencies, 400 beaches from different islands (about $12 \%$ of the recorded beaches) were processed by all four analysts and the standard deviation of the extracted shoreline positions was estimated at less than $0.3 \mathrm{~m}$; this was considered acceptable for the scope of the study. 
However, it should be noted that the primary information used, i.e., satellite imagery snapshots, cannot provide synoptic information at the Aegean archipelago scale, as the available images have been collected in different periods and under variable hydrodynamic conditions. Regarding the beach width estimations, although astronomical tidal effects are small due to the microtidal regime of the Aegean archipelago (tidal ranges in most areas less than about $0.15 \mathrm{~m}$ ) and the generally increased beach slopes, there are still uncertainties as the estimations were based on "snapshots" of the shoreline positions which are very dynamic coastal features controlled, amongst others, by the spatiotemporal variability of the nearshore waves and currents (e.g., Velegrakis et al., 2016). Satellite imagery, as well as other "one-off" landbased, airborne or lidar surveys, provides only snapshots of beach widths which may not represent "mean" conditions; nevertheless, this cannot be avoided when working at large spatial scales (e.g., Allenbach et al., 2015; Vousdoukas et al., 2016a).

Beaches were digitized as polygons and exported to ArcGIS for further analysis. There has been no georectification, as the aim of the exercise has not been to provide definitive locations and elevations of beach features, but to extract/record (horizontal) geospatial characteristics. To this end, a custom made AML (ARC Macro Language, proprietary language for ArcInfo applications in Esri software) script was used to estimate beach areas, lengths, maximum widths and orientations (Allenbach et al., 2015).

In addition to beach dimensions, other relevant information was recorded and codified, including the presence of (a) natural features, such as river mouths, back-barrier lagoons and cliffs, and beachrock outcrops; and (b) artificial features such as coastal protection schemes and backshore infrastructure/assets. Classification of the beach sediments of the Aegean island beaches in terms of sediment texture classes (e.g., sand or gravel) was also carried out on the basis of all available information from the scientific literature/reports (e.g., Monioudi et al., 2016) as well as webbased photographic material.

\subsection{Beach retreat predictions due to sea level rise}

Sea level rise represents a most significant hazard for beaches, forcing their retreat/erosion; a sea level rise $\alpha$ will result in a shoreline retreat $S$ due to erosion of the beach face, the sediments of which are transported/deposited offshore, with the extent/rates of the cross-shore retreat controlled (amongst others) by bed slope, the texture and supply of beach sediments, and the hydrodynamic conditions (e.g., Dean, 2002).

In the present study, seven cross-shore (1-D) morphodynamic models were used to project beach response to SLR: the Bruun (Bruun, 1988), Edelman (Edelman, 1972) and Dean (Dean, 1991) analytical models and the numerical models SBEACH (Larson and Kraus, 1989), Leont'yev
(Leont'yev, 1996), XBeach (Roelvink et al., 2010) and the Boussinesq model, whose hydrodynamic component involves high-order Boussinesq equations (Karambas and Koutitas, 2002). The Bruun model is a widely-used (e.g., Hinkel et al., 2010; Ranasinghe et al., 2013) analytical morphodynamic model that estimates long-term coastal retreat $(S)$ under a SLR $(\alpha)$ on the basis of the equilibrium profile concept; its results are controlled by the height of the beach face and the cross-shore distance between the beach closure depth and the shoreline. The Edelman model estimates beach erosion/retreat using the initial height of the beach face, the water depth at wave breaking and the surf zone width, whereas the Dean model estimates retreats on the basis of the wave height, the water depth at wave breaking and the surf zone width. It should be noted that due to lack of accurate bathymetry data, the necessary input values of the analytical models, i.e., the distance of the shoreline from the closure depth and the width of the surf zone, were estimated on the basis of the beach slope.

The SBEACH model (Larson and Kraus, 1989) is a numerical morphodynamic model consisting of three modules: a hydrodynamic, a sediment transport and a morphological evolution module. It can describe wave transformation in shoaling waters, with the coastal sediment transport controlled by the coastal wave energy fluxes; the sediment continuity equation in a finite-difference scheme and a "stair-step" beach profile discretization is used in its morphological module. The numerical model based on Leont'yev (1996) uses the energetic approach, with the cross-shore wave energy balance controlled by wave propagation angle and dissipation; sediment transport rates are estimated separately for the surf and swash zones. The XBeach model (Roelvink et al., 2010 ) is an open-source, widely used numerical model of the nearshore processes intended to estimate the effects of timevarying storm conditions; it contains a time-dependent wave action balance solver and allows for variations in the wave action over time and over the directional space. Finally, the Boussinesq model used computes nonlinear wave transformation in the surf and swash zone based on a wave propagation module involving high-order Boussinesq equations (Karambas and Koutitas, 2002); its sediment transport module can estimate sheet flow as well as bed and suspended load over uneven sea beds (e.g., Karambas, 2006). Detailed descriptions of the models used can be found elsewhere (e.g., Vousdoukas et al., 2009a; Monioudi et al., 2016).

In the present contribution, all models were used in a stationary mode. Validation of model results was provided through comparisons with the results of physical experiments that took place in the large wave flume (GWK) in Hanover, Germany (Sect. 4.2.1). The models were used in an ensemble mode in order to assess the range of long- and short-term beach retreats/erosion for different beach slopes, sediment grain sizes and wave conditions, and under different scenarios of MSL changes and/or storm sea levels. Two model ensembles were created: a "long-term" ensemble consisting 
of the Bruun, Dean and Edelman analytical models; and a "short-term" ensemble comprising the numerical SBEACH, Leont'yev, XBeach and Boussinesq models. The former is used to assess beach retreat/erosion under MSLR and the latter to assess retreat due to temporary SLR (i.e., due to storm surges and waves). The adopted approach was based on the proposition that as models have differential sensitivity to the controlling environmental factors, ensemble applications may provide "tighter" prediction ranges than the individual models (Sect. 4.2.1).

Experiments were carried out using various plausible energetic wave conditions in the Aegean archipelago (Sect. 2.2), i.e., waves with offshore heights $\left(H_{\mathrm{s}}\right)$ of 1, 1.5, 2, 3 and $4 \mathrm{~m}$ and periods $(T)$ of $4,5,6,7$ and $8 \mathrm{~s}$. Likewise, in order to address the sediment texture variability over the archipelago beaches, experiments were carried out for seven different median $\left(d_{50}\right)$ grain sizes $\left(d_{50}\right.$ of $0.2,0.33,0.50,0.80,1,2$ and $5 \mathrm{~mm}$ ); note that the results of the analytical models are not controlled by beach sediment size. Five (5) different linear profile slopes (bed slopes of 1/10,1/15,1/20,1/25 and $1 / 30)$ and 11 SLR scenarios $(0.05,0.15,0.22,0.30,0.40$, $0.50,0.75,1,1.25,1.50$ and $2 \mathrm{~m}$ ) were examined. Experiments were carried out for all combinations (about 5500 experiments), and the means (best fits) of the lowest and highest projections by all models of the two ensembles were estimated. With regard to combined SLRs, i.e., coastal ESLs due to storm surges and wave set-ups superimposed on the MSLRs (e.g., Vousdoukas et al., 2016b), the long-term and short-term ensembles were used consecutively.

Recent MSLR projections for the area that take into account contributions of ice mass were used (Hinkel et al., 2014): (i) $0.15 \mathrm{~m}$, average of the RCP 4.5 and RCP 8.5 scenarios in 2040; and (ii) 0.5 and $0.7 \mathrm{~m}$ under RCP 4.5 and RCP 8.5 (2100). With regard to short-term SLR, recent trends for extreme sea levels in the Aegean archipelago (up to 0.5$0.6 \mathrm{~m}$ high) (Tsimplis and Shaw, 2010) are used; ESLs in the region are projected to only slightly increase in the future according to recent projections regarding their storm surge component (Androulidakis et al., 2015; Vousdoukas et al., 2016a).

The above approach is designed to project beach retreat/erosion, but not temporary inundation/flooding due to wave run-up. Although the wave run-up is dealt within the numerical models of the ensemble, its effects are manifested in the results only if it induces sediment transport that forces morphological changes (e.g., Leont'yev, 1996). However, wave run-up induced temporary flooding that does not result in beach retreats might also be a significant beach management issue (e.g., Jiménez et al., 2012; Hoeke et al., 2013). Therefore, estimations of wave run-up excursion/inundation were also undertaken on the basis of run-up heights; these were estimated for all tested conditions, using the expressions of Stockdon et al. (2006) which have been validated for the beaches of the Aegean archipelago (Vousdoukas et al., 2009b):

$$
\begin{aligned}
& R_{2 \%}= \\
& 1.1\left(0.35 \beta\left(H_{o} / L_{o}\right)^{1 / 2}+\frac{\left[H_{o} L_{o}\left(0.563 \beta^{2}+0.004\right)\right]^{1 / 2}}{2}\right),
\end{aligned}
$$$$
\text { for all data, and }
$$$$
R_{2} \%=0.043\left(H_{o} / L_{o}\right)^{1 / 2} R_{2} \%=0.043\left(H_{o} / L_{o}\right)^{1 / 2},
$$$$
\text { for dissipative beaches }(\xi<0.3) \text {, }
$$

where $R_{2} \%$, the $2 \%$ exceedance of the peak run-up height, $H_{o}$ and $L_{o}$ are the deep water wave height and length, $\beta$ the beach slope and $\xi$ the Iribarren number $\left(\xi=\beta /\left(H_{o} / L_{o}\right)^{1 / 2}\right)$.

Wave run-up excursions were then calculated from the wave run-up heights $\left(R_{2} \%\right)$ for all tested bed slopes and wave conditions and added to the beach erosion/retreat projections of the seven 1-D cross-shore morphodynamic models to project final flooding excursions $(S(i))$. The best fits of the lower and upper limits of the final projections of flooding by all models were then estimated.

\section{Results}

\subsection{Characteristics of the beaches of the Aegean archipelago}

A total of 3234 beaches were recorded along the coasts of the 58 larger islands of the Aegean archipelago. These beaches were found to be "pocket" beaches, having a total area of about $21.35 \mathrm{~km}^{2}$; this indicates that the total carrying capacity of the Aegean archipelago beaches (i.e., the number of visitors that can be simultaneously hosted) is about 2.135 million according to the Rajan et al. (2013) criterion $\left(10 \mathrm{~m}^{2}\right.$ for each beach user). A rough estimation on the basis of the average number of tourist days spent in the Aegean islands suggests that, with the exception of the busiest months (July and August) during which about 7 million tourist days per month are recorded (SETE, 2016) and many beaches operate close to their full carrying capacity, the archipelago beaches in their present condition still have (as a total) potential for development as environments of leisure.

Most of the Aegean beaches are narrow, with about 59\% of them having recorded maximum widths of less than $20 \mathrm{~m}$ (Fig. 2). Regarding beach sediment type, three different classes were recorded: (i) sandy beaches $(36.4 \%)$, (ii) gravel/pebbled beaches (44.4\%), and (iii) cobble/rocky beaches (about $2 \%$ ). For the remainder of the beaches, no sediment type could be assigned on the basis of the available information (Fig. 2).

Beach orientation was examined by (i) taking into consideration the eight main compass directions and (ii) considering the eight main compass directions for each of the eight island complexes of the Aegean Sea - N. Aegean, Dodecanese, Cyclades, Crete, SW Aegean, Argo-Saronic, Euboea (Evia), and Sporades, Fig. 1. In the first case, occurrence 

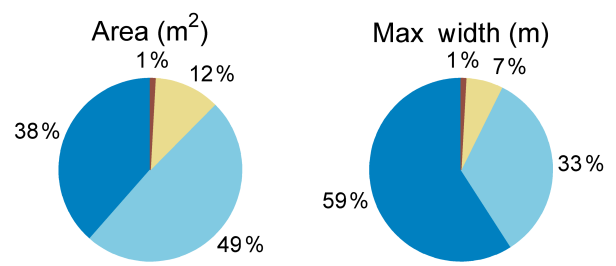

(a)
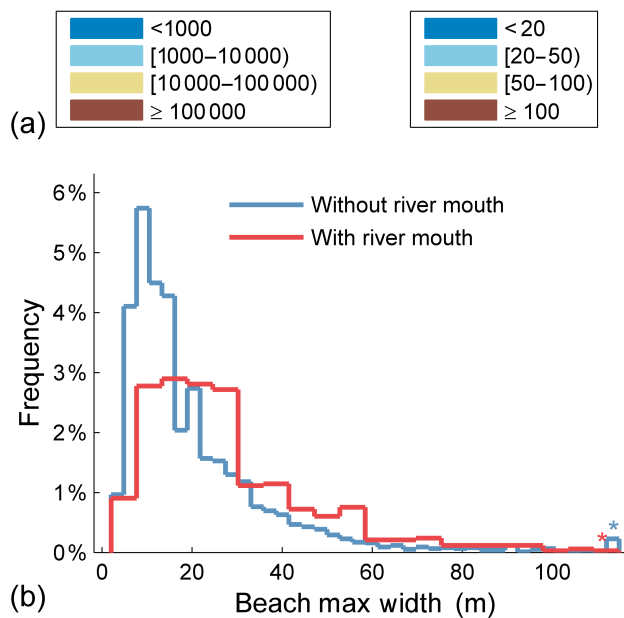
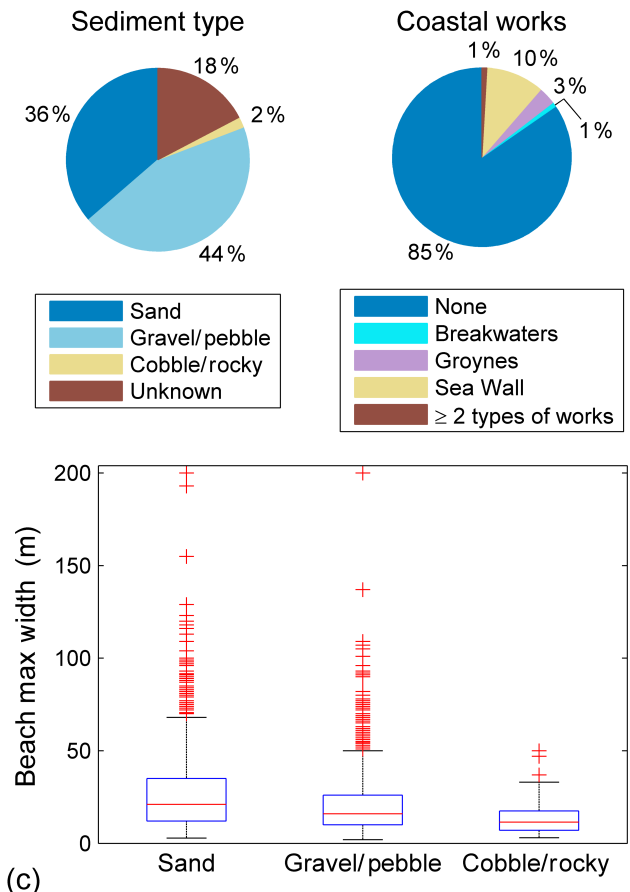

Figure 2. Statistics of the Aegean archipelago beaches. (a) Pie diagrams of major characteristics; (b) relationship between the beach maximum width and the presence of river mouths; and (c) box plots showing relationships between beach widths and sediment types.

of beaches with S, SE and SW orientations appears more prevalent (16.1, 13.9 and $12.5 \%$ respectively) than that of beaches facing towards the other five compass directions; this was found to be statistically significant (Table 1). Prevailing beach orientations were also found to differ over the different island complexes. For example, the prevailing (statistically significant) beach orientations were found to be towards the SE $(18 \%)$ in the Dodecanese islands and towards the S $(22 \%)$ in Crete. There is also significant correlation between beach orientation and recorded maximum width. Statistical tests (Table 1) showed that $\mathrm{W}$ and $\mathrm{SW}$ facing beaches are associated with greater maximum widths $(24.5$ and $24.0 \mathrm{~m}$, respectively).

The above results indicate some hydrodynamic control in the development and maintenance of the Aegean beaches: there are more and wider beaches along the island coasts that are (at least) partially protected from the prevailing northerly wind/waves (Soukissian et al., 2007, 2008). However, the correlation is weak (Table 1) due to other important factors controlling island beach development/maintenance, such as the antecedent topography and geological history, the terrestrial sediment supply and the human development at each individual beach.

In terms of the terrestrial sediment supply, few beaches (about $18 \%$ ) were found to be associated with intermittent (very rarely permanent) flow river mouths; most of those were found in the large islands of the North Aegean (314 out of a total of 728 beaches). Riverine supply appears to be a significant control for both beach width and sediment type; beaches with river mouths are more likely to be wider and built on finer sediments (sands) (Fig. 2 and Table 1).

Another interesting finding is that perched beaches (Gallop et al., 2012) form a significant fraction of the Aegean archipelago beaches; beachrock outcrops (e.g., Vousdoukas et al., 2009a) were recorded on the beach face of $23 \%$ of all beaches. In terms of orientation, although there appears that beaches with beachrocks are more prevalent at the southern coasts of islands (192 out of 744 total occurrences), statistical testing did not show any significant trends (Table 1). Since there could be a significant number of beaches which may contain buried beachrocks (i.e., not outcropping at the time of the analyzed imagery), it seems that beachrocks are quite widespread along the Aegean island beaches.

Coastal protection schemes have been recorded at about $15 \%$ of the Aegean island beaches (Fig. 2a). In comparison, many beaches are associated with coastal development: $80.8 \%$ of all beaches front public and private assets such as coastal roads, housing and tourist infrastructure. The density of these assets is variable, ranging from a coastal road and a few houses found in remote island beaches to the plethora of valuable public and private assets found behind the urban beaches of, e.g., Heraklion (Crete) and Rhodes. Generally, about $32.7 \%$ of the Aegean beaches front coastal infrastructure and assets with moderate to high density. The considerable coastal development, coupled with the narrow widths of 
Table 1. Statistical analysis of the characteristics of the Aegean archipelago beaches.

\begin{tabular}{|c|c|c|c|}
\hline Comparison & Null Hypothesis $\left(H_{0}\right)$ & Statistical test results & Observations \\
\hline $\begin{array}{l}\text { Beach orientation and } \\
\text { occurrence }\end{array}$ & $\begin{array}{l}H_{0}: \text { the data are uniformly dis- } \\
\text { tributed around the compass } \\
\text { rose }\end{array}$ & $\begin{array}{l}\text { Rayleigh's test: } H_{0} \text { rejected } \\
(p<0.001) \text {. Beach orientation not } \\
\text { uniformly distributed over the compass } \\
\text { rose. }\end{array}$ & $\begin{array}{l}\text { Prevailing beach orientation to- } \\
\text { wards the south (S) (occurrence } \\
16.1 \% \text { ) }\end{array}$ \\
\hline $\begin{array}{l}\text { Beach orientation and } \\
\text { maximum width }\end{array}$ & $\begin{array}{l}H_{0}: \text { the eight compass orienta- } \\
\text { tions have equal mean values } \\
\text { regarding maximum width } \\
\left(\mu_{1}=\mu_{2}=\ldots \mu_{8}\right) \\
H_{0}: \quad \rho_{\mathrm{M}}=0, \text { no correla- } \\
\text { tion in the data population }\end{array}$ & $\begin{array}{l}\text { Kruskal-Wallis (Analysis of variance } \\
\text { by ranks): } H_{0} \text { rejected }(p<0.001) \text {. } \\
\text { Mean beach maximum widths differ } \\
\text { with orientation. } \\
\text { Mardia's correlation coefficient (Zar, } \\
\text { 2010): } H_{0} \text { rejected }(p<0.01) \text {. } \\
\text { Significant correlation between orienta- } \\
\text { tion and maximum width. }\end{array}$ & $\begin{array}{l}\text { W and SW facing beaches have } \\
\text { greater maximum widths (mean } \\
\text { maximum widths of } 24.5 \text { and } \\
24 \mathrm{~m} \text { ) }\end{array}$ \\
\hline $\begin{array}{l}\text { Beach orientation and } \\
\text { beachrock occurrence }\end{array}$ & $\begin{array}{l}H_{0} \text { : the two variables are inde- } \\
\text { pendent }\end{array}$ & $\begin{array}{l}\chi^{2} \text { tests for (i) four and (ii) main com- } \\
\text { pass orientations: } \\
H_{0} \text { rejected }(p<0.001) \text {. Small associa- } \\
\text { tion power, Cramer's (i) } V=0.13 \text { and } \\
\text { (ii) } V=0.17 \text {. }\end{array}$ & No significant trend \\
\hline $\begin{array}{l}\text { Sediment type and } \\
\text { presence of river mouth }\end{array}$ & $\begin{array}{l}H_{0}: \text { beach sediment type inde- } \\
\text { pendent of the river mouth pres- } \\
\text { ence }\end{array}$ & $\begin{array}{l}\chi^{2} \text { test: } H_{0} \text { rejected }(p<0.05) . \text { Signifi- } \\
\text { cant correlation, but small power of as- } \\
\text { sociation }(\text { Cramer's } V=0.064)\end{array}$ & $\begin{array}{l}\text { Sand-sized beach sediments } \\
\text { are more associated with river } \\
\text { mouths }\end{array}$ \\
\hline $\begin{array}{l}\text { Beach maximum width } \\
\text { and presence of river } \\
\text { mouth }\end{array}$ & $\begin{array}{l}H_{0}: \text { the sets are independent } \\
\text { (mean values } \\
\left.\mu_{1}=\mu_{2}\right)\end{array}$ & $\begin{array}{l}\text { Student's } t \text { test (two-tailed test): } \\
H_{0} \text { rejected }(p<0.001)\end{array}$ & $\begin{array}{l}\text { Beaches with large maximum } \\
\text { widths are associated with river } \\
\text { mouths (Fig. 2b) }\end{array}$ \\
\hline $\begin{array}{l}\text { Beach sediment type } \\
\text { and maximum width }\end{array}$ & $\begin{array}{l}H_{0}: \text { mean values of the three } \\
\text { categories are equal } \\
\mu_{1}=\mu_{2}=\mu_{3}\end{array}$ & $\begin{array}{l}\text { ANOVA, after splitting the data set into } \\
\text { the three sediment types: } \\
H_{0} \text { rejected }(p<0.001)\end{array}$ & $\begin{array}{l}\text { Beaches with coarse sediments } \\
\text { are associated with smaller } \\
\text { maximum widths (Fig. 2c) }\end{array}$ \\
\hline
\end{tabular}

the Aegean island beaches increase exposure under a variable and changing climate.

\subsection{Predictions of erosion/retreat and flooding for the Aegean island beaches}

\subsubsection{Model sensitivity and validation}

Model sensitivity tests undertaken within the present study have shown that beach retreats are controlled by beach typology. All models show higher retreats with decreasing Iribarren numbers - i.e., for beaches with milder beach slopes $(\beta)$ and/or offshore waves of increased steepness $\left(H_{o} / L_{o}\right)-$ with the exception of the Bruun model whose results are independent of $\xi$ for linear profiles. The most sensitive models to beach slope are the Edelman and SBEACH models, and the least sensitive is the XBeach model; with regard to the offshore wave climate, XBeach appears to be the most sensitive, while Leont'yev and Boussinesq appear to be the least sensitive models. The effect of sediment texture is not always clear, although a weak negative correlation between beach retreat and the median sediment size $\left(d_{50}\right)$ might be discerned in the numerical models; analytical model results are inde- pendent of the beach sediment texture. Generally, models showed differential sensitivity to initial conditions and forcing, which justifies their collective use in ensembles.

Model results have been compared with those by physical experiments conducted at the large wave flume in early 2013 (details in Vousdoukas et al. 2014). In these experiments, the initial slope of the beach was set to about $1 / 15$, tested waves had an offshore height $(H)$ of $1 \mathrm{~m}$ and a period $(T)$ of $5 \mathrm{~s}$, and the seabed consisted of well-sorted sand of median grain size $\left(d_{50}\right)$ equal to $0.3 \mathrm{~mm}$. Three SLR scenarios were tested (rises of $0.2,0.4$ and $0.6 \mathrm{~m}$ ), with the initial profiles of these experiments controlled by the final profile (wave forcing only) of the first experiment (i.e., the test without level rise). Simulation times were set to $3000 \mathrm{~s}$.

In Fig. 3, profiles by the numerical models Leont'yev, SBEACH, XBeach and Boussinesq under the baseline level as well as three increased sea levels $(+0.2,+0.4$ and $+0.6 \mathrm{~m})$ are compared against those that resulted from the physical experiments. It appears that there are some discrepancies, particularly with regard to the dynamics of the offshore bar and trough. The Leonty'ev and XBeach models seem to considerably "smooth" these features, whereas the SBEACH and Boussinesq results tend to better represent the results of the 
physical experiments; the best performance was that of the Boussinesq model (Fig. 3). Nonetheless, there appears to be a good agreement between the beach retreats estimated by the models and those recorded during the physical experiments (Fig. 3 and Table 2). The Leont'yev, SBEACH and Boussinesq models appear to slightly underestimate beach retreats, and XBeach appears to overestimate them. The Bruun and Edelman models appear to overestimate beach retreats under higher SLRs, whereas the Dean model appear to overestimate them under all SLRs tested.

When the models are used in an ensemble mode, the comparison between the retreats projected by the numerical models (short-term retreat) and those recorded in the physical experiments improves (Table 2). Conversely, analytical models tend to overestimate beach retreats by up to $20 \%$. Interestingly, when the results of all (7) analytical and numerical models are combined in a unified ensemble, then retreat overestimations decrease to less than $10 \%$ for the tested SLRs.

The above results refer to natural profiles. In order to relate the validation to the linear profiles used here, further tests were undertaken. In these tests, the models were run using an "equivalent" linear profile having a slope of 1/15 to compare with the results of the physical experiments. The equivalent profile was estimated using the best linear fit to the natural profiles used in the physical experiment (between water depths of 3.5 and elevations of $1.5 \mathrm{~m}$ ).

The results of this exercise are shown in Table 3. Generally, the comparison showed that, at least for the conditions tested, the results of the models set with the equivalent linear profile were reasonably close to those of the physical experiments, with the comparison worsening with increasing water levels. When the numerical models are used as an (shortterm) ensemble, beach retreat forced by waves is only overestimated; under SLR, however, ensemble projections improve (overestimations of up to $19 \%$, Table 3). Regarding the analytical models, the long-term ensemble gave improved projections, with differences between models and experiments ranging from about 3 to $11 \%$.

\subsubsection{Beach erosion and inundation/flooding projections}

Modeling results show that sea level rise will cause shoreline retreats as well as significant morphological changes (Fig. 4). Numerical models showed differential profile changes in both breaker and surf zones, supporting their use in an ensemble mode.

Models displayed differential behavior for almost all tested conditions, showing, as expected, significant ranges of results (Fig. 5) due to the varying initial conditions and forcing used, i.e., different bed slopes, sediment sizes, wave conditions and SLRs. The means (best fits) of the lowest and highest projections of all models were calculated. It was found that the "low" mean of the beach retreat projections by the short-term ensemble (i.e., the best fit of the lowest projections from the four numerical models) is given by $S=0.1 \alpha^{2}+9.7 \alpha+0.4$ and the "high" mean by $S=0.7 \alpha^{2}+28.5 \alpha+4.8$ (Fig. 5a), where $S$ is the beach retreat and $\alpha$ is the SLR. Also, the low projection mean of the longterm ensemble is given by $S=0.1 \alpha^{2}+10 \alpha+0.3$ and the high projection mean by $S=1.6 \alpha^{2}+29.8 \alpha+2.3$ (Fig. 5b). Ranges in beach temporary inundation/flooding due to wave runup combined with $(\alpha)$ episodic (short-term) SLRs (Fig. 5c) were estimated as $S(i)=0.1 \alpha^{2}+9.7 \alpha+4$ (minimum) and $S(i)=-0.7 \alpha^{2}+31.2 \alpha+27.2$ (maximum) and with longterm SLRs (Fig. 5d) as $S(i)=0.4 \alpha^{2}+10.1 \alpha+3.7$ (minimum) and $S(i)=0.4 \alpha^{2}+30 \alpha+28.1$ (maximum).

Ranges of decreases in dry beach widths were projected through the comparison between the ranges of beach retreat/erosion $(S)$ and the recorded maximum widths of the 3234 pocket beaches. Ranges in beach temporary inundation/flooding were estimated by the comparison between the ranges of combined beach retreat and wave run-up excursions $(S(i))$ and the beach maximum widths. In Table 4, estimations are presented for nine SLR scenarios: (i) $0.15,0.5$ and $0.7 \mathrm{~m}$ MSLRs according to recent projections for the area (Hinkel et al., 2014) using the long-term ensemble; (ii) shortterm SLRs due to storm surges and waves of $0.2,0.4$ and $0.6 \mathrm{~m}$ using the short-term ensemble; and (iii) combined MSLRs and short-term SLRs of 0.55, 1.1 and $1.3 \mathrm{~m}$ using the long- and short-term ensembles consecutively.

According to the projections of the long-term ensemble, MSLRs of $0.15,0.5$ and $0.7 \mathrm{~m}$ will result to beach retreats/erosion of about 1.8-6.8, 5.3-17.6 and 7.3-24 m, respectively, whereas short-term ensemble estimates show that storm-induced levels of $+0.2,+0.4,+0.6 \mathrm{~m}$ could result in ranges of beach retreat/erosion of about 2.3-10.6, 4.3-16.3, 5.3-19.3 and 6.2-22.2 m, respectively (Table 4). For the considered SLR scenarios, there will be significant impacts on the Aegean archipelago beaches as shown by the percentages of beaches that are projected to be eroded/shifted landward to a distance equal to between 50 and $100 \%$ of their maximum width (Table 4).

Even under an MSLR of $0.15 \mathrm{~m}$ (RCPs 4.5 and 8.5 in 2040), there could be substantial impacts on the basis of the mean minimum and maximum projections of the long-term ensemble (Table 4$)$. Temporary inundation $(S(i))$ could overwhelm between 4.9 and $81 \%$ of the beaches, flooding (occasionally) $4.6-80 \%$ of the beaches fronting currently existing coastal infrastructure/assets. Under an MSLR of $0.5 \mathrm{~m}$ (RCP 4.5, 2100), projected impacts will be severe. From 5 to $54 \%$ of all Aegean beaches will be completely eroded in the absence of appropriate coastal defences, whereas between about 18 and $90 \%$ of all beaches are projected to be occasionally overwhelmed by flooding. For 2100 , under the high emission scenario (RCP 8.5, MSLR of $0.7 \mathrm{~m}$ ), impacts could be catastrophic (Table 4 and Fig. 6): 12.4-68 and 28$93 \%$ of Aegean island beaches will be completely eroded and occasionally overwhelmed by flooding, respectively. Associated infrastructure/assets are also projected to be greatly 


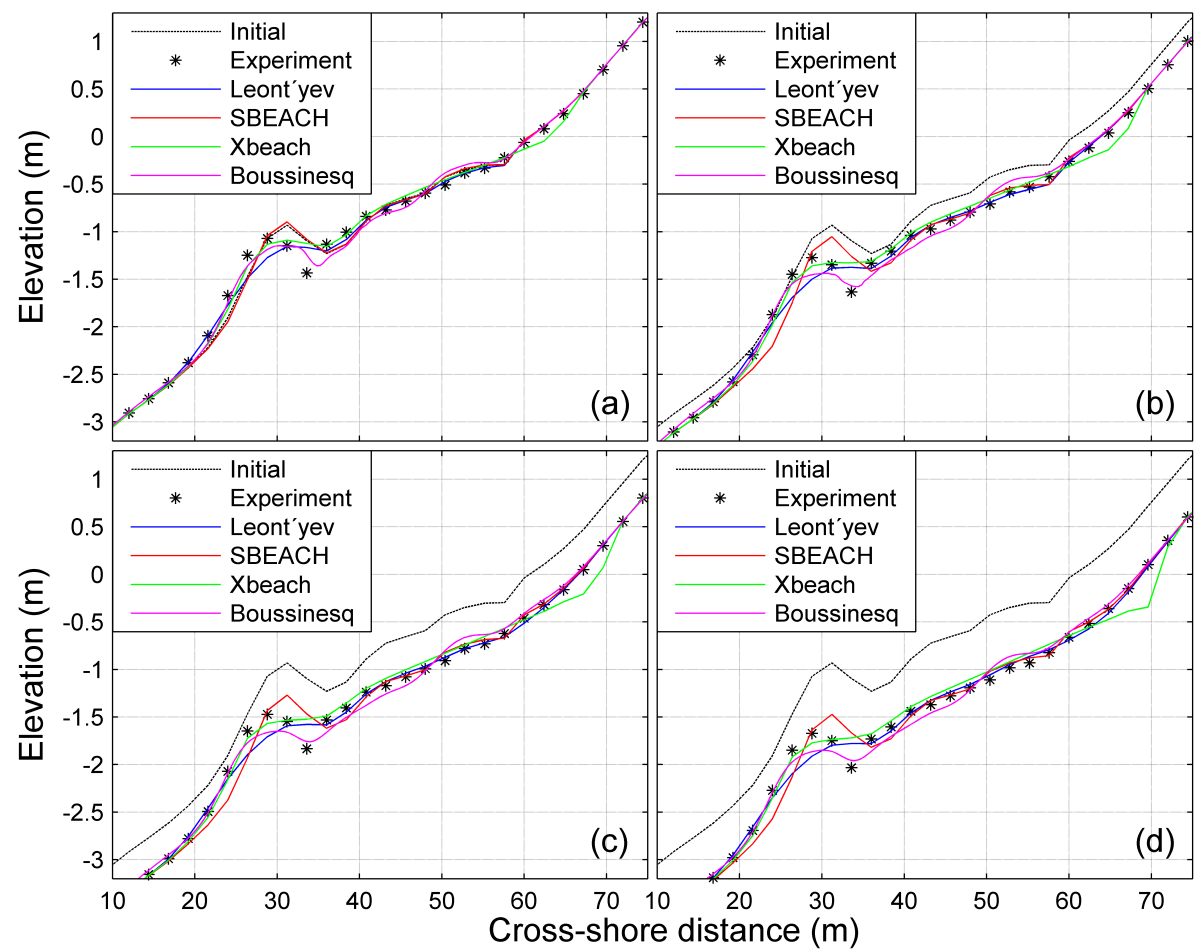

Figure 3. Profiles by numerical models plotted against results from physical experiments at the large wave flume (GWK, Hanover): (a) initial/present water level; (b) water level rise of $0.2 \mathrm{~m}$; (c) water level rise of $0.4 \mathrm{~m}$; and (d) water level rise of $0.6 \mathrm{~m}$. Both numerical and physical experiments were set up for the same initial (nonlinear) profile. Simulation times for the numerical experiments set to $3000 \mathrm{~s}$ to match those of the physical experiment.

Table 2. Comparison of results from models and physical experiments. Negative values represent erosion. Key: SLR, sea level rise; Exper, physical experiment; Leo, Leont'yev model; SB, SBEACH model; Xb, XBeach model; Bous, Boussinesq model; ST Ens, Short-term ensemble; Br, Bruun model; Edel, Edelman model; Dean, Dean model; and LT Ens, Long-term ensemble.

\begin{tabular}{lrrrrrrrrrr}
\hline \multirow{2}{*}{ SLR $(\mathrm{m})$} & \multicolumn{8}{c}{ Shoreline retreat/erosion or advance/accretion $(\mathrm{m})$} \\
\cline { 2 - 11 } & Exper & Leo & SB & Xb & Bous & ST Ens & Br & Edel & Dean & LT Ens \\
\hline 0 & -0.35 & -0.01 & 0.02 & -2.32 & -0.06 & -0.59 & - & - & - & - \\
0.2 & -3.57 & -3.2 & -3.04 & -5.63 & -3.0 & -3.72 & -3.01 & -3.09 & -6.7 & -4.27 \\
0.4 & -6.23 & -5.94 & -5.83 & -8.35 & -5.6 & -6.43 & -6.13 & -6.43 & -8.82 & 7.13 \\
0.6 & -8.66 & -8.22 & -8.02 & -10.27 & -7.9 & -8.60 & -9.25 & -9.97 & -11.5 & -10.24 \\
\hline
\end{tabular}

impacted, with 12-66 and 26-92\% of all beaches fronting currently existing assets projected to be lost to beach erosion and occasionally overwhelmed by flooding, respectively.

According to the mean low projections of the short-term ensemble, storm coastal sea levels of +0.2 and $+0.4 \mathrm{~m}$ will result in moderate (temporary) beach retreats $(0.1-2.3 \%$ of all beaches will retreat more than their maximum width) and temporary flooding $(5-12.7 \%$ of the beaches will be occasionally completely flooded). On the basis of the mean high projections (forced by the high wave conditions expected in storms, see also Tsoukala et al., 2016), beach retreats and flooding will be substantial with severe reductions in dry beach widths and potential damage to assets located at the back of the beach. About 27 and $51 \%$ of all Aegean beaches will retreat by more than their maximum width and 82 and $87 \%$ will be completely overwhelmed by temporary flooding under short-term SLRs of 0.2 and $0.4 \mathrm{~m}$, respectively (Table 4).

In the case of a $0.4 \mathrm{~m}$ short-term SLR, up to 50 and $86 \%$ of all beaches fronting assets will be affected by beach retreat/erosion and temporary flooding, respectively (Fig. 6), whereas impacts will be more severe under higher coastal sea levels $(+0.6 \mathrm{~m}$, Table 4$)$. The picture does not change much, even when projections are adjusted for the maximum overestimation observed in the results of the numerical models (by $19 \%$ ) when linear profiles were used (Sect. 4.2.1); for exam- 
Table 3. Comparison of results by models and physical experiments. Models used an equivalent linear profile slope of $1 / 15$ to represent the natural profile of the physical experiment (see text). Negative values represent beach retreat/erosion. Key: SLR, sea level rise; Exper, physical experiment; Leo, Leont'yev model; SB, SBEACH model; Xb, XBeach model; Bous, Boussinesq model; ST Ens, Short-term ensemble; Br, Bruun model; Edel, Edelman model; Dean, Dean model; and LT Ens, Long-term ensemble.

\begin{tabular}{lrrrrrrrrrr}
\hline \multirow{2}{*}{ SLR $(\mathrm{m})$} & \multicolumn{8}{c}{ Shoreline retreat/erosion or advance/accretion $(\mathrm{m})$} \\
\cline { 2 - 11 } & Exper & Leo & SB & Xb & Bous & ST Ens & Br & Edel & Dean & LT Ens \\
\hline 0 & -0.35 & -0.34 & -0.02 & -3.23 & 0.0 & -0.9 & - & - & - & - \\
0.2 & -3.57 & -3.58 & -3.2 & -7.00 & -3.03 & -4.20 & -3 & -3.07 & -4.05 & -3.37 \\
0.4 & -6.23 & -6.67 & -6.25 & -10.47 & -5.9 & -7.32 & -6 & -6.3 & -7.05 & -6.45 \\
0.6 & -8.66 & -9.73 & -9.25 & -13.35 & -8.8 & -10.28 & -9 & -9.69 & -10.05 & -9.58 \\
\hline
\end{tabular}

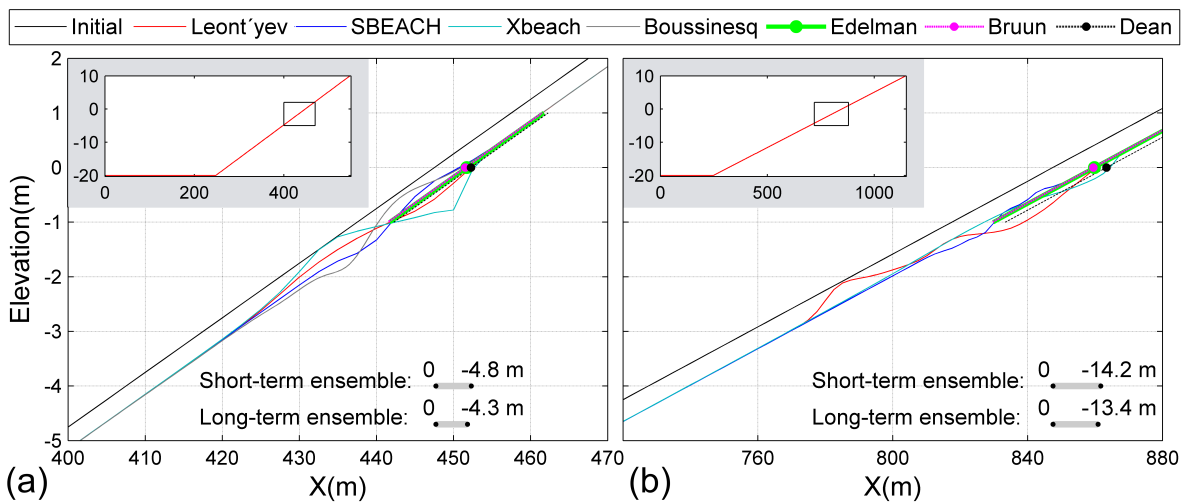

Figure 4. Examples of morphodynamic changes in the profile of the upper part of the beach (see inset) and mean retreats of the two ensembles for an SLR of $0.4 \mathrm{~m}$. (a) Offshore (at $20 \mathrm{~m}$ water depth) wave height $(H)$ of $1 \mathrm{~m}$, period $(T)$ of $5 \mathrm{~s}$ and median $\left(d_{50}\right)$ sediment grain size of $0.8 \mathrm{~mm}$, linear beach profile with a $1 / 10$ slope; (b) Offshore (at $20 \mathrm{~m}$ water depth) wave height $(H)$ of $2 \mathrm{~m}$, period $T$ of $6 \mathrm{~s}$ and median $\left(d_{50}\right)$ sediment grain size of $0.33 \mathrm{~mm}$, linear profile with $1 / 30$ slope. Origin of $x$ axis is at $20 \mathrm{~m}$ water depth.

ple, for a $0.4 \mathrm{~m}$ level rise, up to 37 and $84 \%$ of all beaches fronting assets will be fully eroded and flooded, respectively.

The worst impacts are projected from the combined mean and short-term SLRs. In 2040, in the case that storm-induced sea levels of $+0.4 \mathrm{~m}$ are combined with a projected MSLR of $0.15 \mathrm{~m}$ (combined SLR of $0.55 \mathrm{~m}$ ), 8-68\% of beaches are projected to be (at least temporarily) eroded and $21-91 \%$ of beaches flooded. In 2100, superimposition of storm levels on the projected MSLRs will have devastating effects. A combined sea level rise of $1.1 \mathrm{~m}$ (e.g., a storm-induced extreme level of $+0.6 \mathrm{~m}$ superimposed on an MSLR of $0.5 \mathrm{~m}$, RCP 4.5) will have very severe impacts; indeed (Figs. 6 and 7) $31-88 \%$ of all beaches will be completely (at least temporarily) eroded (29-87\% of all beaches fronting assets) under the low and high mean projections of the ensemble, respectively, with $48-96 \%$ of all beaches occasionally overwhelmed by flooding (Table 4).

A combined SLR of $1.3 \mathrm{~m}$ (RCP 8.5, an MSLR of $0.7 \mathrm{~m}$ combined with a storm-induced coastal sea level of $+0.6 \mathrm{~m}$ ) represents a "doomsday" scenario for the beaches of the Aegean archipelago. Based on the low projections of the combined ensembles, about $75 \%$ of the beaches will be shifted landward (and/or drowned) to a distance equal to
$50 \%$ of their maximum dry width, whereas about $39 \%$ of all beaches will be (at least temporarily) completely eroded; about $37 \%$ of beaches fronting existing assets will be fully eroded and $54 \%$ fully flooded.

According to the high ensemble estimates, it is projected that almost $91 \%$ of all beaches will be completely eroded, at least at the time of the storm event $(90 \%$ of all beaches fronting assets); about $97 \%$ of all beaches will also be flooded temporarily (Table 4).

When projections are adjusted for overestimations observed in the validation exercise due to the use of linear profiles (Sect. 4.2.1), projected impacts are still devastating: 35$89 \%$ of all beaches will be (at least temporarily) completely eroded and $48-86 \%$ flooded whereas, according to the high estimates, 88 and $96 \%$ of all beaches fronting assets will be completely eroded and flooded, respectively.

It should be noted that projected impacts do not account for vertical land motions (Poulos et al., 2009). Moreover, since other significant erosion factors such as the diminishing coastal sediment supply are not considered, the above projections may actually underestimate future beach retreat/erosion and flooding at the Aegean archipelago beaches. 


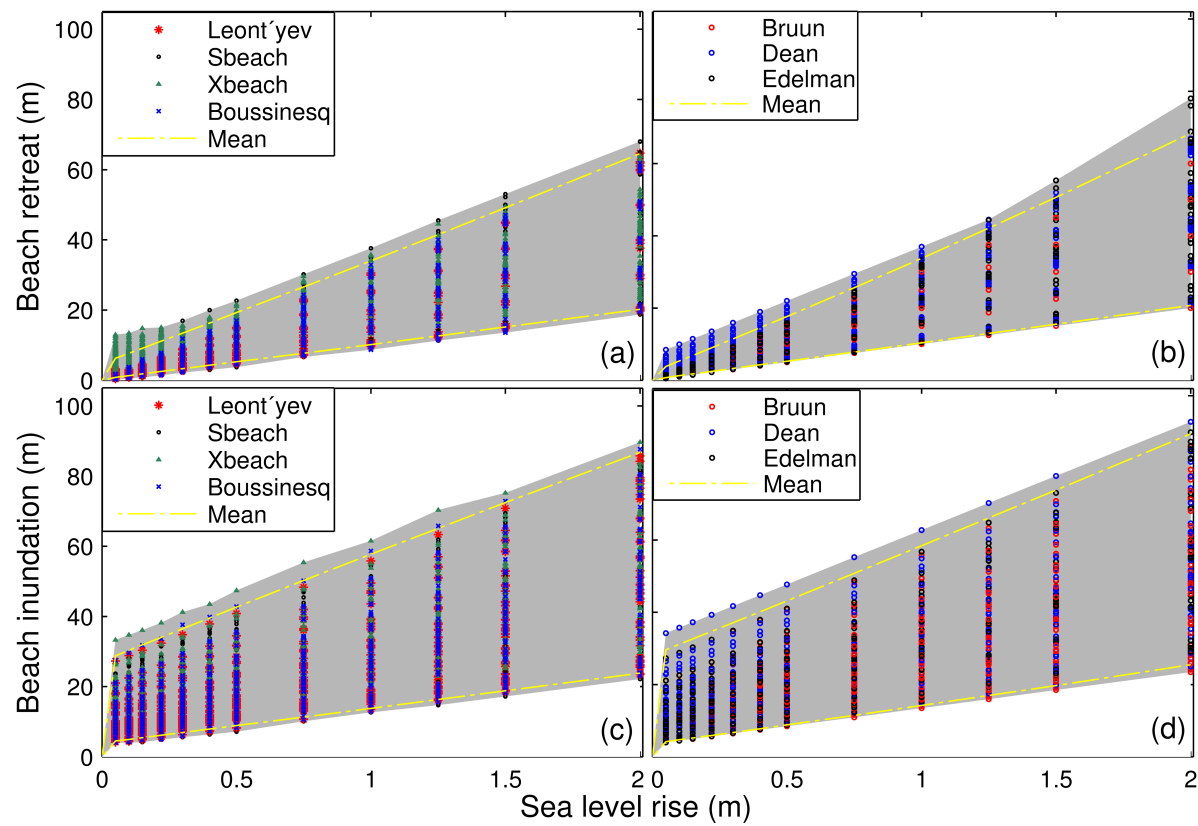

Figure 5. (a, b) Projections of beach retreat/erosion and (c, d) temporary inundation/flooding due to (a, c) short-term and (b, d) long-term SLR. Projections are for different beach slopes, sediment sizes and wave conditions. The means of the highest and lowest projections of all models in the ensembles are shown as yellow stippled lines.

Table 4. Minimum and maximum mean estimates of beach retreat $(S)$ and inundation/flooding $(S(i))$ by the long-term, short-term and combined ensembles and the empirical model of Stockdon et al. (2006). Ranges of cross-shore retreat/erosion $(R)$ and temporary inundation/flooding $(F)$ for the beaches of the Aegean archipelago are projected by comparing the highest and lowest mean $S$ and $S(i)$ with the maximum width of the 3234 Aegean archipelago beaches under different SLRs. Numbers $(N)$ and percentages of beaches where backshore infrastructure/assets are projected to be affected by beach retreat/erosion and flooding are also shown.

\begin{tabular}{|c|c|c|c|c|c|c|c|c|c|c|c|c|}
\hline \multirow{3}{*}{ SLR (m) } & & & \multirow{3}{*}{$\begin{array}{r}S \\
(\mathrm{~m})\end{array}$} & \multirow{3}{*}{$\begin{array}{l}S(i) \\
(\mathrm{m})\end{array}$} & \multirow{3}{*}{\multicolumn{2}{|c|}{$\begin{array}{c}R \\
\text { Equal to } 50 \% \text { of } \\
\text { max. width }(\%)\end{array}$}} & \multirow{3}{*}{\multicolumn{2}{|c|}{$\begin{array}{c}R \quad F \\
\text { Equal to max. } \\
\text { width }(\%)\end{array}$}} & \multicolumn{2}{|c|}{$R$} & \multicolumn{2}{|c|}{$F$} \\
\hline & & & & & & & & & \multicolumn{4}{|c|}{ Beaches with assets affected } \\
\hline & & & & & & & & & $N$ & $\%$ & $N$ & $\%$ \\
\hline \multirow{6}{*}{ Long-term } & 0.15 & Min & 1.8 & 5.2 & 0.6 & 27.4 & 0.0 & 4.9 & 0 & 0.0 & 119 & 4.6 \\
\hline & & Max & 6.8 & 32.6 & 39.1 & 96.4 & 8.2 & 81.1 & 203 & 7.8 & 2086 & 79.8 \\
\hline & 0.5 & Min & 5.3 & 8.8 & 27.5 & 54.2 & 5.0 & 17.6 & 120 & 4.6 & 437 & 16.7 \\
\hline & & Max & 17.6 & 43.2 & 84.4 & 98.3 & 54.2 & 89.7 & 1368 & 52.4 & 2320 & 88.8 \\
\hline & 0.7 & Min & 7.3 & 10.9 & 43.2 & 64.3 & 12.4 & 27.6 & 306 & 11.7 & 688 & 26.3 \\
\hline & & Max & 24 & 49.3 & 91.5 & 99.1 & 68.0 & 92.6 & 1732 & 66.3 & 2400 & 91.8 \\
\hline \multirow{6}{*}{ Short-term } & 0.2 & Min & 2.3 & 5.9 & 2.4 & 30.9 & 0.1 & 5.0 & 2 & 0.1 & 122 & 4.7 \\
\hline & & Max & 10.6 & 33.4 & 64.3 & 96.6 & 27.5 & 82.1 & 684 & 26.2 & 2113 & 80.9 \\
\hline & 0.4 & Min & 4.3 & 7.9 & 17.4 & 47.9 & 2.3 & 12.7 & 49 & 1.9 & 315 & 12.1 \\
\hline & & Max & 16.3 & 39.6 & 81.1 & 97.8 & 51.3 & 87.2 & 1293 & 49.5 & 2249 & 86.1 \\
\hline & 0.6 & Min & 6.2 & 9.8 & 34.7 & 59.1 & 7.9 & 21.5 & 195 & 7.5 & 537 & 20.6 \\
\hline & & Max & 22.2 & 45.7 & 90.2 & 98.8 & 66.5 & 90.7 & 1695 & 64.9 & 2343 & 89.7 \\
\hline \multirow{6}{*}{ MSLR + Short-term } & 0.55 & Min & 6 & 9.6 & 34.7 & 59.0 & 7.9 & 21.4 & 195 & 7.5 & 535 & 20.5 \\
\hline & & Max & 23.2 & 46.4 & 91.0 & 98.8 & 68.0 & 91.0 & 1730 & 66.2 & 2354 & 90.1 \\
\hline & 1.1 & Min & 11.6 & 15.2 & 68.0 & 78.8 & 30.8 & 47.8 & 763 & 29.2 & 1204 & 46.1 \\
\hline & & Max & 40.3 & 63.6 & 97.9 & 99.7 & 88.0 & 96.2 & 2270 & 86.9 & 2506 & 95.9 \\
\hline & 1.3 & Min & 13.5 & 17.2 & 74.6 & 82.8 & 39.1 & 54.1 & 977 & 37.4 & 1364 & 52.2 \\
\hline & & Max & 46.2 & 69.7 & 98.8 & 99.7 & 91.0 & 96.8 & 2354 & 90.1 & 2526 & 96.7 \\
\hline
\end{tabular}




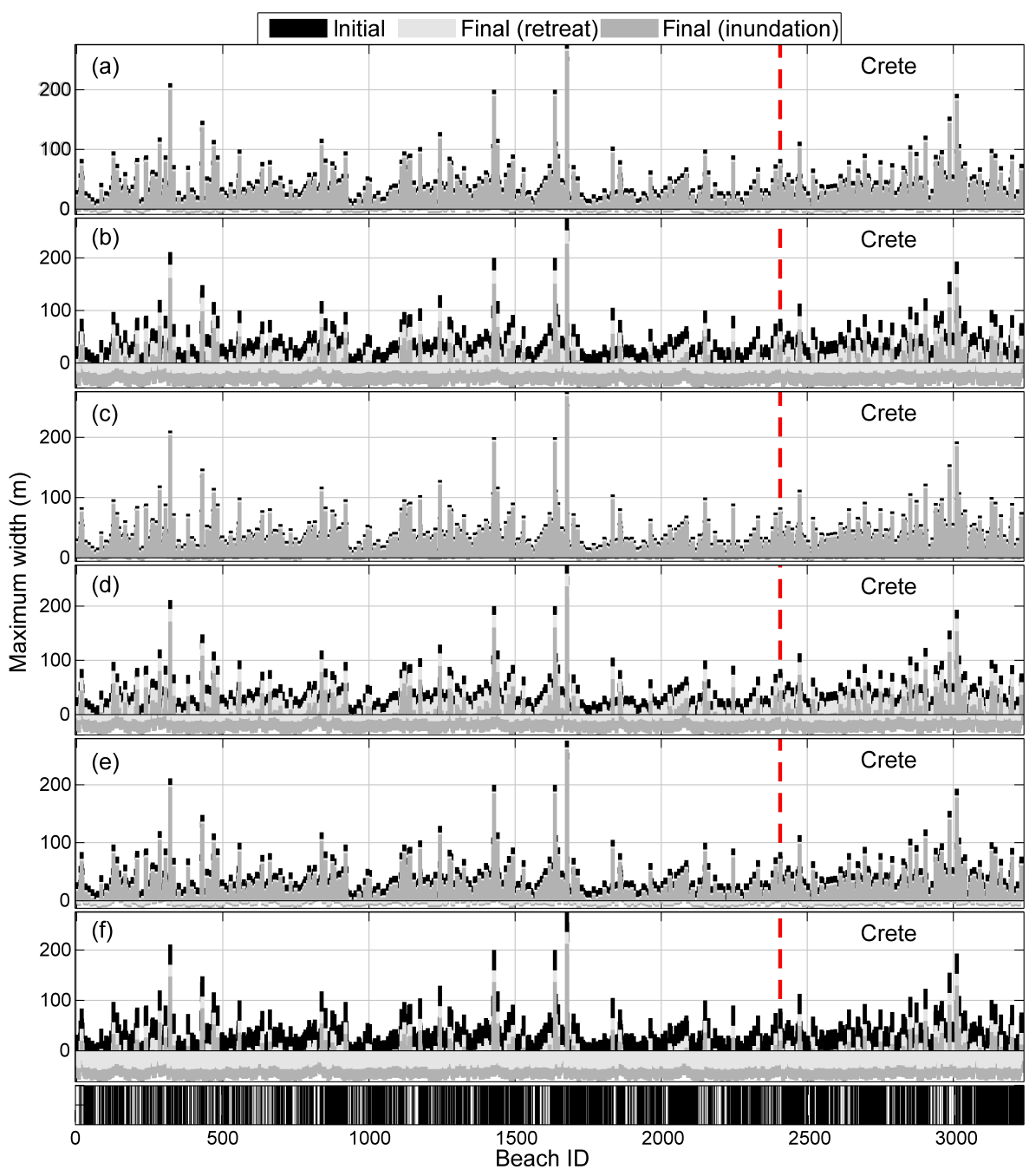

Figure 6. Minimum and maximum retreat and flooding of Aegean archipelago beaches for different SLR scenarios on the basis of the low and high means, respectively, of the ensemble projections. (a) Minimum and (b) maximum retreat and flooding under an MSLR of $0.7 \mathrm{~m}$. (c) Minimum and (d) maximum retreat and flooding under a storm-induced level of $+0.4 \mathrm{~m}$. (e) Minimum and (f) maximum retreat and flooding under a combined long- and short-term SLR of $1.1 \mathrm{~m}$ (see text). Initial and final (after SLR) maximum beach widths are shown. Final widths $<0$ show beaches lost or shifted landward or flooded by their entire maximum width. Black bars show currently existing infrastructure/assets fronted by beaches.

\section{Discussion and conclusions}

The analysis of the first systematic record of the geospatial characteristics of the beaches of the Aegean archipelago has provided interesting findings. Aegean island beaches are narrow pocket beaches $(59 \%$ were recorded having maximum recorded widths $<20 \mathrm{~m}$ ) characterized by limited terrestrial sediment supply and fronting a moderate (as a total) load of backshore development; about $81 \%$ of the Aegean beaches currently front coastal infrastructure/assets with $33 \%$ fronting moderate to high coastal development. At the same time, only $15 \%$ of beaches are associated with some form of existing coastal protection. Moreover, at least $23 \%$ of the Aegean beaches exhibit outcropping beachrocks at their beach faces. In addition to aesthetic considerations and the safety risks that slippery beachrock surfaces might pose to beach users (Vousdoukas et al., 2009c), beach face beachrocks can also induce ecological changes and promote beach sediment removal (e.g., Vousdoukas et al., 2009b, 2012), decreasing the carrying capacity of the archipelago beaches and constraining their potential as environments of leisure (Kontogianni et al., 2014).

Development and maintenance of the Aegean beaches may be (at least partially) controlled by hydrodynamics, as more and wider beaches occur along the southern and western coasts of the islands that are relatively protected from the prevailing N-NE waves. Maximum beach widths were found to correlate with sediment type and terrestrial sediment sup- 


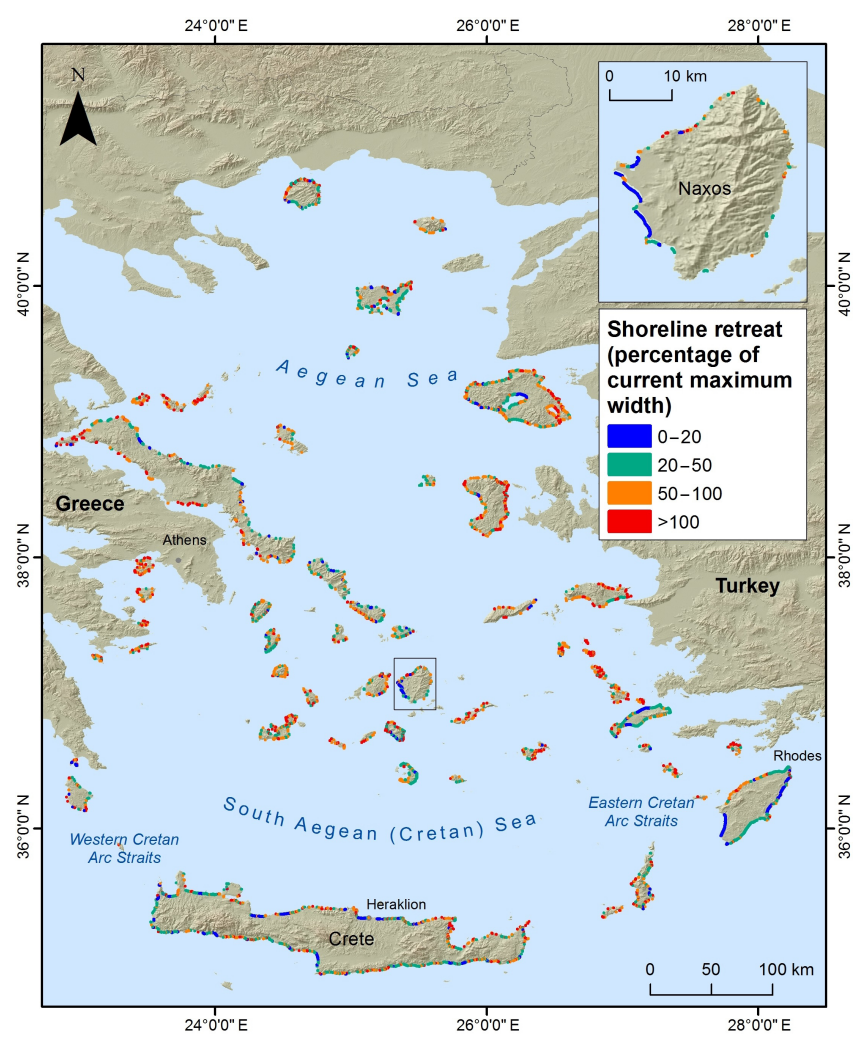

Figure 7. Projections of minimum beach retreat under a combined SLR of $1.1 \mathrm{~m}$ (see text) showing Aegean beaches projected to retreat by distances equal to different percentages of their initial maximum widths. In the inset, projections for the beaches of Naxos (Cyclades) are shown in larger scale for detail.

ply; sandy beaches are wider, as are those associated with river outlets. With regard to the carrying capacity of the archipelago beaches, these appear to have potential (as a total) for further development as environments of leisure; nevertheless, better spatial distribution and a lengthening of the period of beach tourism should be considered.

Aegean island beaches appear particularly vulnerable to SLR. Our modeling results project severe erosion and flooding under SLR from as early as 2040, particularly under the combined effects of the projected MSLR and storm-induced sea levels (Table 4). By 2100, beach erosion from combined MSLR and storm events is projected to be very substantial, with potentially devastating impacts on both coastal infrastructure and tourism. For example, under an MSLR of $0.5 \mathrm{~m}$ (RCP 4.5), a short-term coastal sea level rise due to storm surges and waves of $0.6 \mathrm{~m}$ is projected to result in complete erosion of between 31 (minimum) and $88 \%$ (maximum) of all beaches (29-87\% of beaches currently fronting coastal infrastructure and assets), at least temporarily. In addition, between 46 and $96 \%$ of the coastal infrastructure and assets behind the Aegean island beaches are projected to be temporarily flooded during such an event. Regarding the Aegean island tourism, this will be negatively affected by the pro- jected large decreases in dry beach width, a critical control of the beach recreational use, value and resilience (e.g., Yang et al., 2012). Under increasing beach erosion/retreat and flooding, the long-term recreational value of the Aegean archipelago beaches as well as the value of associated assets may fall considerably (e.g., Gopalakrishnan et al., 2011). As a recent study projects substantial changes in the return periods of ESLs in the E. Mediterranean for the end of the 21st century (Vousdoukas et al., 2017); the projected impacts on both beaches and coastal infrastructure/assets are worrying.

Against this background, it appears that plans to respond effectively to the projected beach erosion risk should be urgently drawn up with different adaptation options analyzed. Options based on the ecosystem approach should be considered first in order to protect both beaches and backshore ecosystems and infrastructure/assets (e.g., Peduzzi et al., 2013), although "hard" works might, in some cases, be deemed necessary. However, the significance of beaches as critical economic resources and the low effectiveness of hard coastal works (e.g., breakwaters) to protect beaches from MSLR indicate that beach nourishment schemes will also be required, at least for the most economically important beaches. As marine aggregates constitute the most suitable, but often scarce (Peduzzi, 2014), material for beach nourishment, particular care should be taken to ensure sustainability of marine aggregate deposits (Velegrakis et al., 2010). The significance of such deposits should be certainly considered in future marine spatial plans as a matter of priority (see also EU Directive 2014/89/EU).

A primary tool to manage the assets and economic activities at risk is the introduction of effective policies and regulation. An underpinning principle of coastal management under SLR should be the introduction of effective precautionary controls on future coastal development, e.g., through regulation that allocates buffer zones ("setback" zones) behind retreating coastlines. It is our opinion that, on the basis of these results, there is an urgent need to adopt and implement relevant regulation for the Aegean archipelago.

A way forward could be the ratification by Greece of the 2009 ICZM Protocol to the Barcelona Convention, which prescribes setback zones (Art. 8.2a) and has already been ratified by the EU (Council Decision 2010/631/EU). However, there are also challenges, e.g., those related to the setback zone demarcation and risk allocation, (e.g., Sano et al., 2010; Gibbs et al., 2013) that can only be alleviated by publicly transparent criteria and decisions (e.g., Abbott, 2013). Assessments of beach retreat/erosion and flooding are required at various scales that are science-based and, at the same time, accessible by coastal planners, managers, stakeholders and the wider public for the planning and smooth implementation of setback zones as well as the prioritization in the allocation of resources for adaptation.

The approach adopted in the present study to assess impacts of the SLR presents certain advantages. Existing methodologies/tools for rapid assessment of coastal/beach 
erosion due to MSLR and extreme events at large scales (e.g., Hinkel et al., 2010; Ramieri et al., 2011; Khouakhi et al., 2013) have limitations stemming from, amongst others, (a) their requirements for coastal digital elevation models (DEMs) of high resolution/accuracy and (b) the limited general consideration for major controls (e.g., hydrodynamics). At the same time, advanced modeling approaches (e.g., Vousdoukas et al., 2016b) in addition to detailed environmental information commonly require experienced operators and high computation costs that may make them impractical to coastal planners/managers (e.g., McLeod et al., 2010).

The present approach, which compares ranges of SLRinduced beach retreat and flooding under different initial conditions and hydrodynamic forcing with beach maximum widths, is not limited by the resolution/accuracy of available coastal DEMs or the availability of detailed environmental information (e.g., Jiménez et al., 2012) and can be easily incorporated in other beach vulnerability tools (e.g., Alexandrakis et al., 2015) and used in areas with limited human resources. Nevertheless, there are also constraints. Projections are based on the assumption that beaches comprise inexhaustible sediment reservoirs with no lateral sediment losses; cross-shore modeling obviously cannot resolve such issues. In addition, the approach is not designed to account for other erosion-controlling factors, such as geological controls, coastal sedimentary budgets, and extreme event duration and sequencing (e.g., Gallop et al., 2012; Corbella and Stretch, 2012); the presence of artificial beach protection schemes and/or protecting nearshore ecosystems (e.g., Peduzzi et al., 2013); and the effects of coastal use (e.g., Bi et al., 2013). However, the aim of the exercise has not been to replace detailed modeling studies for individual beaches, but to provide ranges of beach erosion and flooding at a large (archipelago) scale.

Data availability. All the datasets (inputs/outputs) created by our research team and used for the research can be found on the following link which is publicly accessible: http://erabeach.aegean.gr/ wp-content/uploads/2017/03/Monioudi-et-al.-2017-Data.zip.

Competing interests. The authors declare that they have no conflict of interest.

Acknowledgements. This research has been co-financed by the European Union (European Social Fund-ESF) and Greek national funds through the Operational Program "Education and Lifelong Learning" of the National Strategic Reference Framework (NSRF) - Research Funding Program: THALES (Project ISLA). The senior authors (INM, AFV and AEC) also acknowledge the support from the ERA-Beach Project during the writing-up of the research; the program is $85 \%$ co-funded by the EEA Grants, 2009-2014, and $15 \%$ by the Public Investments Programme (PIP) of the Hellenic Republic. M. I. Vousdoukas acknowledges funding from the
European Union Seventh Framework Programme FP7/2007-2013 under grant agreement no. 603864 (HELIX: "High-End cLimate Impacts and eXtremes"; www.helixclimate.eu) as well as by the JRC institutional project CoastAlRisk.

Edited by: O. Katz

Reviewed by: two anonymous referees

\section{References}

Abbott, T.: Shifting shorelines and political winds - The complexities of implementing the simple idea of shoreline setbacks for ocean front developments in Maui, Hawaii, Ocean Coast. Manage., 73, 13-21, 2013.

Alexandrakis, G., Manasakis, C., and Kampanis, N. A.: Valuating the effects of beach erosion to tourism revenue. A management perspective, Ocean Coast. Manage., 111, 1-11, 2015.

Allenbach, K., Garonna, I., Herold, C., Monioudi, I., Giuliani, G., Lehmann, and Velegrakis, A. F.: Black Sea beach vulnerability to sea level rise, Environ. Sci. Policy, 46, 95-109, 2015.

Androulidakis, Y. S., Kourafalou, V. H., Krestenitis, Y. N., and Zervakis, V.: Variability of deep water mass characteristics in the North Aegean Sea: The role of lateral inputs and atmospheric conditions, Deep-Sea Res. I, 67, 55-72, 2012.

Androulidakis, Y. S., Kombiadou, K. D., Makris, C. V., Baltikas, V. N., and Krestenitis, Y. N.: Storm surges in the Mediterranean Sea: Variability and trends under future climatic conditions, Dynam. Atmos. Oceans, 71, 56-82, 2015.

Bi, X., Lu, Q., and Pan, X.: Coastal use accelerated the regional sea-level rise, Ocean Coast. Manage., 82, 1-6, 2013.

Bosom, E. and Jiménez, J. A.: Storm-induced coastal hazard assessment at regional scale: application to Catalonia (NW Mediterranean), Adv. Geosci., 26, 83-87, doi:10.5194/adgeo-26-832010, 2010.

Bruun, P.: The Bruun Rule of erosion by sea level rise: A discussion on large-scale two- and three-dimensional usages, J. Coastal Res., 4, 622-648, 1988.

Calafat, F. M., Chambers, D. P., and Tsimplis, M. N.: On the ability of global sea level reconstructions to determine trends and variability, J. Geophys. Res., 119, 7840-7853, 2014.

Cisneros, H. M. A., Revollo-Sarmiento, N. V., Delrieux, C. A., Piccolo, M. C., and Perillo, G. M. E.: Beach carrying capacity assessment through image processing tools for coastal management, Ocean Coast. Manage., 130, 138-147, 2016.

Conte, D. and Lionello, P.: Characteristics of large positive and negative surges in the Mediterranean sea and their attenuation in future climate scenarios, Global Planet. Change, 111, 159-173, 2013.

Corbella, S. and Stretch, D. D.: Predicting coastal erosion trends using non-stationary statistics and process-based models, Coast. Eng., 70, 40-49, 2012.

Dean, R. G.: Equilibrium beach profiles: characteristics and applications, J. Coastal Res., 7, 53-84, 1991.

Dean, R. G.: Beach nourishment: Theory and practice, in: Advanced Series on Ocean Eng., World Scientific Publishing Company, Singapore, 18, 399 pp., 2002. 
Defeo, O. and McLachlan, A.: Global patterns in sandy beach macrofauna: Species richness, abundance, biomass and body size, Geomorphology, 199, 106-114, 2013.

Ding, Y., Kuiry, S. N., Elgohry, M., Jia, Y., Altinakar, M. S., and Yeh, K.-C.: Impact assessment of sea-level rise and hazardous storms on coasts and estuaries using integrated processes model, Ocean Eng., 71, 74-95, 2013.

ECLAC: An assessment of the economic impact of climate change on the transportation sector in Barbados, UN Economic Commission for Latin America and the Caribbean ECLAC, Technical Report LC/CAR/L309, 44 pp., 2011.

Edelman, T.: Dune erosion during storm conditions, in: Proceedings of the 13th International Conference on Coast. Eng., ASCE, 1305-1312, 1972.

Eurosion: Living with coastal erosion in Europe: Sediment and Space for Sustainability, Part II, DG Environment, EC, available at: http://www.eurosion.org/reports-online/part2.pdf (last access: March 2017), 29 May 2004.

Gallop, S. L., Bosserelle, C., Eliot, I., and Pattiaratchi, C. B.: The influence of limestone reefs on storm erosion and recovery of a perched beach, Cont. Shelf Res., 47, 16-27, 2012.

Ghermandi, A. and Nunes, P. A. L. D.: A global map of coastal recreation values: Results from a spatially explicit meta-analysis, Ecol. Econ., 86, 1-15, 2013.

Gibbs, M. T., Thébaud, O., and Lorenz, D.: A risk model to describe the behaviours of actors in the houses falling into the sea problem, Ocean Coast. Manage., 80, 73-79, 2013.

Gopalakrishnan, S., Smith, M. D., Slott, J. M., and Brad Murray, A.: The value of disappearing beaches: A hedonic pricing model with endogenous beach width, J. Environ. Econ. Manag., 61, 297-310, 2011.

Hall, C. M., Scott, D., and Gössling, S.: The Primacy of Climate Change for Sustainable International Tourism, Sustain. Dev., 21, 112-121, 2013.

Hinkel, J., Nicholls, R. J., Vafeidis, A. T., Tol, R. S. J., and Avagianou, T.: Assessing risk of and adaptation to sea-level rise in the European Union: An application of DIVA, Mitigation and Adaptation Strategies for Global Change, 15, 703-719, 2010.

Hinkel, J., Lincke, D., Vafeidis, A. T., Perrette, M., Nicholls, R. G., Tol, R. S., Marzeion, B., Fettweis, X., Ionescu, C., and Levermann, A.: Coastal flood damages and adaptation costs under 21st century sea-level rise, P. Natl. Acad. Sci. USA, 111, 3292-3297, 2014.

Hoeke, R. K., McInnes, K. L., Kruger, J. C., McNaught, R. J., Hunter, J. R., and Smithers, S. G.: Widespread inundation of Pacific islands triggered by distant-source wind-waves, Global Planet. Change, 108, 128-138, 2013.

IOBE: The impact of tourism on Greek Economy, Foundation for Economic \& Industrial Research, 43 pp., available at: http: //iobe.gr/docs/research/RES_05_E_01092012REP_GR.pdf (last access: March 2017), 2012 (in Greek).

IPCC: Climate Change 2013: The Physical Science Basis, Contribution of Working Group I to the Fifth Assessment Report of the Intergovernmental Panel on Climate Change, edited by: Stocker, T. F., Qin, D., Plattner, G.-K., Tignor, M., Allen, S. K., Boschung, J., Nauels, A., Xia, Y., Bex, V., and Midgley, P. M., Cambridge University Press, Cambridge, UK, New York, USA, 2013.

IPCC SREX: Managing the Risks of Extreme Events and Disasters to Advance Climate Change Adaptation, A Special Report of
Working Groups I and II of the Intergovernmental Panel on Climate Change IPCC, edited by: Field, C. B., Barros, V., Stocker, T. F., Qin, D., Dokken, D. J., Ebi, K. L., Mastrandrea, M. D., Mach, K. J., Plattner, G.-K., Allen, S. K., Tignor, M., and Midgley, P. M., Cambridge University Press, Cambridge, UK, New York, USA, 582 pp., 2012.

Jiménez, J. A., Bosom, E., Valdemoro, H. I., and Guillén, J.: Storminduced damages along the Catalan coast (NW Mediterranean) during the period 1958-2008, Geomorphology, 143-144, 24-33, 2012.

Karambas, T.: Prediction of sediment transport in the swash zone by using a nonlinear wave model, Cont. Shelf Res., 26, 599-609, 2006.

Karambas, T. V. and Koutitas, C.: Surf and swash zone morphology evolution induced by nonlinear waves, J. Waterw. Port C.-ASCE, 128, 102-113, 2002.

Khouakhi, A., Snoussi, M., Niazi, S., and Raji, O.: Vulnerability assessment of Al Hoceima bay (Moroccan Mediterranean coast): a coastal management tool to reduce potential impacts of sealevel rise and storm surges, J. Coastal Res., SI 65, 968-973, 2013.

Kontogianni, A. D., Damigos, D., Tourkolias, C., Vousdoukas, M. I., Velegrakis, A. F., Zanou, B., and Skourtos, M.: The social cost of coastal erosion: eliciting beach users' willingness to pay for protecting European beaches from beachrock processes, Ocean Coast. Manage., 98, 167-175, 2014.

Krestenitis, Y. N., Androulidakis, Y. S., Kontos, Y. N., and Georgakopoulos, G.: Coastal inundation in the north-eastern Mediterranean coastal zone due to storm surge events, Journal of Coastal Conservation, 15, 353-368, 2011.

Larson, M. and Kraus, N. C.: SBEACH: numerical model for simulating storm-induced beach change; report 1: empirical foundation and model development, Technical Report - US Army Coast. Eng. Research Center, Technical Report CERC-89-9, 115 pp., 1989.

Leont'yev, I. O.: Numerical modelling of beach erosion during storm event, Coast. Eng., 29, 187-200, 1996.

Mamoutos, G., Tragou, E., and Kakagiannis, G.: Mean sea level changes in the Greek Seas, in 6th Panhellenic Conference in Management and Improvement of Coastal Zones, Athens, Greece, November 2014, 335-344, 2014.

Marcos, M., Jordà, G., Gomis, D., and Pérez, B.: Changes in storm surges in Southern Europe from a regional model under climate change scenarios, Global Planet. Change, 77, 116-128, 2011.

McArthur, S.: Why Carrying Capacity Should be a Last Resort, 2015, in: Challenges in Tourism Research, edited by: Singh, T. V., Channel View Publications, 288-302, 2015.

McLeod, E., Poulter, B., Hinkel, J., Reyes, E., and Salm, R.: Sealevel rise impact models and environmental conservation: A review of models and their applications, Ocean Coast. Manage., 53, 507-517, 2010.

Monioudi, I. N., Karditsa, A., Chatzipavlis, A., Alexandrakis, G., Andreadis, O. P., Velegrakis, A. F, Poulos, S. E., Ghionis, G., Petrakis, S., Sifnioti, D., Hasiotis, T., Lipakis, M., Kampanis, N., Karambas, T., and Marinos, E.: Assessment of the vulnerability of the eastern Cretan beaches (Greece) to sea level rise, Reg. Environ. Change, 16, 1951-1962, 2016.

Neumann, B., Vafeidis, A. T., Zimmerman, J., and Nicholls, R. J.: Future Coastal Population Growth and Exposure to Sea-Level 
Rise and Coastal Flooding - A Global Assessment, PLoS ONE, 10, e0118571, doi:10.1371/journal.pone.0118571, 2015.

Nicholls, R. J. and Cazenave, A.: Sea-level rise and its impact on coastal zones, Science, 328, 1517-1520, 2010.

Parker, A., Saad Saleem, M., and Lawson, M.: Sea-level trend analysis for coastal management, Ocean Coast. Manage., 73, 63-81, 2013.

Paula, D. P., Dias, J. M. A., Ferreira, O., and Morais, J. O.: High-rise development of the sea-front at Fortaleza (Brazil): Perspectives on its valuation and consequences, Ocean Coast. Manage., 77, 14-23, 2013.

Peduzzi, P.: Sand, rarer than one thinks, Article reproduced from United Nations Environment Programme (UNEP) Global Environmental Alert Service (GEAS), Environmental Development, 11, 208-218, 2014.

Peduzzi, P., Velegrakis, A. F., Estrella, M., and Chatenoux, B.: Integrating the role of ecosytems in disaster risk and vulnerability assessments: Lessons from the Risk and Vulnerability Assessment Methodology Development Project (RiVAMP) in Negril Jamaica, in: The role of Ecosystems in Disaster Risk Reduction, edited by: Renaud, F. G., United Nations University Press, ISBN13: 978-9280812213, 109-139, 2013.

Phillips, M. R. and Jones, A. L.: Erosion and tourism infrastructure in the coastal zone: Problems, consequences and management, Tourism Manage., 27, 517-524, 2006.

Poulos, S. E.: Origin and distribution of the terrigenous component of the unconsolidated surface sediment of the Aegean floor: A synthesis, Cont. Shelf Res., 29, 2045-2060, 2009.

Poulos, S. E., Ghionis G., and Maroukian, H.: Sea-level rise trends in the Attico-Cycladic region (Aegean Sea) during the last 5000 years, Geomorphology, 107, 10-17, 2009.

Prinos, P.: Climate change effects on the Greek seas and coastal areas - the research project THALIS-CCSEAWAVS, in: 6th Panhellenic Conference on Coastal Zones Management and Improvement, Athens, 24-27 November 2014, 315-324, 2014.

Rajan, B., Varghese, V. M., and Pradeepkumar, A. P.: Beach Carrying Capacity Analysis for Sustainable Tourism Development in the South West Coast of India, Environmental Research, Engineering and Management, 1, 67-73, 2013.

Ramieri, E., Hartley, A., Barbanti, A., Duarte Santos, F., Laihonen, P., Marinova, N., and Santini, M.: Methods for assessing coastal vulnerability to climate change, ETC CCA Background Paper, Copenhagen (DK) 8-9 June 2011, European Topic Centre on Climate Change Impacts, Vulnerability and Adaptation European Environment Agency, 76 pp., available at: http://www. oannes.org.pe/ (last access: March 2017), 2011.

Ranasinghe, R., Duong, T. M., Uhlenbrook, S., Roelvink, D., and Stive, M.: Climate-change impact assessment for inletinterrupted coastlines, Nature Climate Change, 3, 83-87, 2013.

Roelvink, D., Reniers, A., Van Dongeren, A., Van Thiel de Vries, J., McCall, R., and Lescinski, J.: Modeling storm impacts on beaches, dunes and barrier islands, Coast. Eng., 56, 1133-1152, 2009

Roelvink, D., Reniers, A., van Dongeren, A., van Thiel de Vries, J., Lescinski, J., and McCall, R.: Xbeach Model Description and Manual, Unesco-IHE Institute for Water Education, Deltares and Delft University of Technology, 106 pp., 2010.
Sano, M., Marchard, M., and Medina, R.: Coastal setbacks for the Mediterranean: a challenge for ICZM, Journal of Coastal Conservation, 14, 33-39, 2010.

SETE: Association of the Greek Touristic Businesses, http://sete. gr/el/statistika-vivliothiki/statistika/ (last access: March 2017), 2016.

Short, A. D. and Jackson, D. W. T.: Beach Morphodynamics, in: Treatise on Geomorphology, edited by: Shroder, J. and Sherman, D. J., 10, 106-129, 2013.

Skliris, N., Sofianos, S. S., Gkanasos, A., Axaopoulos, P., Mantziafou, A., and Vervatis, V.: Long-term sea surface temperature variability in the Aegean Sea, Advances in Oceanography and Limnology, 2, 125-139, 2011.

Smith, A. B. and Katz, R. W.: U.S. Billion-dollar Weather and Climate Disasters: Data Sources, Trends, Accuracy and Biases, Nat. Hazards, 67, 387-410, 2012.

Soukissian, T., Hatzinaki, M., Korres, G., Papadopoulos, A., Kallos, G., and Anadranistakis, E.: Wind and wave atlas of the Hellenic seas, Hellenic Centre for Marine Research Publications, HCMR, 2007.

Soukissian, T., Prospathopoulos, A., Hatzinaki, M., and Kabouridou, M.: Assessment of the wind and wave climate of the Hellenic Seas using 10-Year hindcast results, The Open Ocean Eng., $1,1-12,2008$.

Stockdon, H. F., Holman, R. A., Howd, P. A., and Sallenger, J. A. H.: Empirical parameterization of setup, swash, and runup, Coast. Eng., 53, 573-588, 2006.

Theocharis, A., Georgopoulos, D., Lascaratos, A., and Nittis, K.: Water masses and circulation in the central region of the Eastern Mediterranean: Eastern Ionian, South Aegean and North West Levantine, 1986-1987, Deep-Sea Res. II, 40, 1121-1142, 1993.

Tsimplis, M., Marcos, M., Colin, J., Somot, S., Pascual, A., and Shaw, A. G. P.: Sea level variability in the Mediterranean Sea during the 1990 on the basis of two 2D and one 3D model, J. Marine Syst., 78, 109-123, 2009.

Tsimplis, M. N. and Shaw, A. G. P.: Seasonal sea level extremes in the Mediterranean Sea and at the Atlantic European coasts, Nat. Hazards Earth Syst. Sci., 10, 1457-1475, doi:10.5194/nhess-101457-2010, 2010.

Tsimplis, M. N., Calafat, F. M., Marcos, M., Jorda, G., Gomis, D., Fenoglio-Marc, L., Struglia, M. V., Josey, S. A., and Chambers, D. P.: The effect of the NAO on sea level and on mass changes in the Mediterranean Sea, J. Geophys. Res.-Oceans, 118, 944-952, 2013.

Tsoukala, V. K., Chondros, M., Kapelonis, Z. G., Martzikos, N., Lykou, A., Belibassakis, K., and Makropoulos, C.: An integrated wave modelling framework for extreme and rare events for climate change in coastal areas - the case of Rethymno, Crete, Oceanologia, 58, 71-89, 2016.

UNECE: Climate Change Impacts and Adaptation for International Transport Networks, Expert Group Report, ITC UN Economic Commission for Europe ECE/TRANS/238, 223 pp., available at: http://www.unece.org/fileadmin/DAM/trans/main/ wp5/publications/climate_change_2014.pdf (last access: March 2017), 2013.

Valdemoro, H. I. and Jiménez, J. A.: The influence of shoreline dynamics on the use and exploitation of Mediterranean tourist beaches, Coast. Manage., 34, 405-423, 2006. 
Velegrakis, A. F, Vousdoukas, M. I., Andreadis, O., Pasakalidou, E., Adamakis, G., and Meligonitis, R.: Impacts of dams on their downstream beaches: A case study from Eresos coastal basin, Island of Lesvos, Greece, Mar. Georesour. Geotec., 26, 350-371, 2008.

Velegrakis, A. F., Ballay, A., Poulos, S., Radzevičius, R., Bellec, V., and Manso, F.: European marine aggregates resources: Origins, usage, and mining techniques, J. Coastal Res., SI 51, 1-14, 2010.

Velegrakis, A. F., Trygonis, V., Chatzipavlis, A. E., Karambas, T., Vousdoukas, M. I., Ghionis, G., Monioudi, I. N., Hasiotis, T., Andreadis, O., and Psarros, F.: Shoreline variability of an urban beach fronted by a beachrock reef from video imagery, Nat. Hazards, 83, 201-222, doi:10.1007/s11069-016-2415-9, 2016.

Vousdoukas, M. I., Velegrakis, A. F., and Karambas, T. V.: Morphology and sedimentology of a microtidal beach with beachrocks: Vatera, Lesbos, NE Mediterranean, Cont. Shelf Res., 29, 19371947, 2009a.

Vousdoukas, M. I., Velegrakis, A. F., Dimou, K., Zervakis, V., and Conley, D. C.: Wave run-up observations in microtidal, sedimentstarved beaches of the Eastern Mediterranean, J. Marine Syst., 78, 537-547, 2009b.

Vousdoukas, M. I., Velegrakis, A. F, Kontogianni, A., and Makrykosta, N. E.: Implications of the cementation of beach sediments (beachrock formation) for the recreational use of the beach, Tourism Manage., 30, 544-552, 2009c.

Vousdoukas, M. I., Velegrakis, A. F., Paul, M., Dimitriadis, C., Makrykosta, E., and Koutsoubas, D.: Field observations and modeling of wave attenuation over colonized beachrocks, Cont. Shelf Res., 48, 100-109, 2012.
Vousdoukas, M. I., Kirupakaramoorthy, T., Oumeraci, H., de la Torre, M., Wübbold, F., Wagner, B., and Schimmels, S.: The role of combined laser scanning and video techniques in monitoring wave-by-wave swash zone processes, Coast. Eng., 83, 150-165, 2014.

Vousdoukas, M. I., Voukouvalas, E., Annunziato, A., Giardino, A., and Feyen, L.: Projections of extreme storm surge levels along Europe, Clim. Dynam., 47, 3171-3190, doi:10.1007/s00382016-3019-5, 2016a.

Vousdoukas, M. I., Voukouvalas, E., Mentaschi, L., Dottori, F., Giardino, A., Bouziotas, D., Bianchi, A., Salamon, P., and Feyen, L.: Developments in large-scale coastal flood hazard mapping, Nat. Hazards Earth Syst. Sci., 16, 1841-1853, doi:10.5194/nhess-161841-2016, 2016b.

Vousdoukas, M. I., Mentaschi, L., Voukouvalas, E., Verlaan, M., and Feyen, L.: Extreme sea levels on the rise along Europe's coasts, Earth's Future, doi:10.1002/2016EF000505, 2017.

$\mathrm{Xu}, \mathrm{S}$. and Huang, W.: Effects of sea level rise on frequency analysis of $1 \%$ annual maximum water levels in the coast of Florida, Ocean Eng., 71, 96-102, 2013.

Yang, B., Madden, M., Kim, J., and Jordan, T. R.: Geospatial analysis of barrier island beach availability to tourists, Tourism Manage., 33, 840-854, 2012.

Zar, J. H.: Biostatistical analysis, 5th ed., Prentice Hall PTR, 658 pp., ISBN-13: 978-0321656865, 2010.

Zervakis, V., Georgopoulos, D., and Drakopoulos, P.: The role of the North Aegean in triggering the recent Eastern Mediterranean climatic changes, J. Geophys. Res., 105, 26103-26116, 2000. 